\author{
RESEARCH ARTICLE \\ 10.1029/2019JC015160 \\ Key Points: \\ - We study the paths and intensity of \\ recirculation and northward \\ transfer in the subtropical and \\ tropical waters of the South Atlantic \\ - The change in heat and freshwater \\ transport is calculated along these \\ pathways \\ - Most heat is incorporated by \\ intermediate waters that upwell \\ several hundred meters as they flow \\ north along the eastern boundary
}

Correspondence to:

A. Cabré,

annanusca@gmail.com

Citation:

Cabré, A., Pelegrí, J. L., \&

Vallès-Casanova, I. (2019).

Subtropical-tropical transfer in the

South Atlantic Ocean. Journal of

Geophysical Research: Oceans, 124,

4820-4837. https://doi.org/10.1029/

2019JC015160

Received 19 MAR 2019

Accepted 17 MAY 2019

Accepted article online 25 MAY 2019

Published online 12 JUL 2019

(c)2019. American Geophysical Union. All Rights Reserved.

\section{Subtropical-Tropical Transfer in the South Atlantic Ocean}

\author{
A. Cabré ${ }^{1} \mathbb{D}$, J. L. Pelegrí ${ }^{1} \mathbb{D}$, and I. Vallès-Casanova ${ }^{1}[\mathbb{D}$ \\ ${ }^{1}$ Institut de Ciències del Mar, CSIC, Barcelona, Spain
}

\begin{abstract}
Here we explore the water transfer between the subtropical and tropical gyres of the South Atlantic Ocean to better understand its unique equatorward heat delivery. A Lagrangian technique is applied to the reanalysis product GLORYS2V4 in order to trace back the western boundary flow in the tropical (North Brazil Undercurrent, NBUC) and subtropical (Brazil Current) gyres. Most of the northward NBUC core transport $\left(14.9 \mathrm{~Sv}\right.$ at $8^{\circ} \mathrm{S}$ ) arrives from the eastern boundary subtropical current (Benguela Current) via the zonal South Equatorial Current. This subtropical-tropical transfer represents the core of the returning limb of the Atlantic meridional overturning circulation and accounts for most of the observed increase in heat and salt-volume transports $\left(0.18 \mathrm{PW}\right.$ and $0.19 \mathrm{~Sv}$ from $30^{\circ} \mathrm{S}$ to $8^{\circ} \mathrm{S}$, respectively) across the South Atlantic. The NBUC also includes Antarctic Intermediate Water below $400 \mathrm{~m}\left(7.4 \mathrm{~Sv}\right.$ at $\left.8^{\circ} \mathrm{S}\right)$ coming from the interior subtropical gyre, as well as water from the current's surface and peripheral components coming from the tropical gyre $\left(13.3 \mathrm{~Sv}\right.$ at $\left.8^{\circ} \mathrm{S}\right)$. The Brazil Current $\left(9.9 \mathrm{~Sv}\right.$ at $\left.29^{\circ} \mathrm{S}\right)$ is mostly composed of subtropical water originating in the upper $800 \mathrm{~m}$ west of the eastern boundary current at $30^{\circ} \mathrm{S}(8.5 \mathrm{~Sv})$, with a minor contribution of surface tropical water that transfers to the subtropics (1.4 Sv).
\end{abstract}

\section{Introduction}

The South Atlantic plays a crucial role in the returning limb of the Atlantic meridional overturning circulation (AMOC), being the only basin that transfers heat equatorward from the subtropics to the tropics to compensate for the southward transfer of North Atlantic Deep Water (NADW; Ganachaud \& Wunsch, 2000; Garzoli et al., 2013; Talley, 2003). However, the exchange pathways between the subtropical and tropical gyres in the South Atlantic are poorly understood, due to both an historical lack of observations and the complex interaction between the upper-thermocline gyres and the AMOC.

The South Atlantic subtropical gyre is characterized by an anticyclonic (anticlockwise) circulation, with the isopycnals (sea surface height) deepening (rising) toward the gyre center located in the western half of the basin (e.g., Garzoli et al., 2013; Schmid, 2014). The western boundary current of this subtropical gyre is the Brazil Current (BC), and its southern limit is the South Atlantic Current, starting at the BrazilMalvinas Confluence near $39-40^{\circ} \mathrm{S}$ and flowing east between about $43^{\circ}$ and $47^{\circ} \mathrm{S}$, on the northern side of the subantarctic fronts (e.g., Boebel et al., 1999; Garzoli, 1993; Gordon, 1989; Jullion et al., 2010; Orúe-Echevarría et al., 2019). The subtropical water masses continue northward in the eastern side as the Benguela Current (Garzoli \& Gordon, 1996) and finally flow back to the western boundary as the South Equatorial Current (SEC).

The tropical gyre meets with the subtropical gyre along the SEC, before turning north along the western boundary as the North Brazil Undercurrent (NBUC). A fraction of this near-surface current recirculates into the equatorial ocean via the Equatorial Undercurrent (and its southern and northern branches) and upwells in the central and eastern equatorial ocean. This upwelled water is then carried southward mostly by Ekman surface flows before subducting back toward the northwest, hence joining the SEC and completing what is called the subtropical cell (STC, not to be confused with subtropical gyre; Hazeleger \& Drifjhout, 2006; Schott et al., 2004; Schmid, 2014).

The bifurcation latitude between the northward and southward western boundary currents, defining the western end of the tropical-subtropical border, shifts poleward with depth (Stramma \& England, 1999). Surface water masses $(0-100 \mathrm{~m})$ bifurcate around $14^{\circ} \mathrm{S}$ (Rodrigues et al., 2007) where the southward BC originates. The South Atlantic Central Water bifurcates around $21^{\circ} \mathrm{S}$ and the Antarctic Intermediate Water (AAIW) near $28^{\circ} \mathrm{S}$ (Stramma \& England, 1999). This results both in the downstream deepening of the BC towards the Brazil-Malvinas Confluence (Rocha et al., 2014) and the shoaling of the NBUC toward the tropics (see schematics in Soutelino et al., 2013). 
The presence of the AMOC modifies the picture of two semi-isolated wind-driven gyres, accounting for the transfer of water masses from the subtropical to the tropical gyre mostly along the SEC (Garzoli \& Matano, 2011; Lazar et al., 2001). Another consequence of the AMOC is that a portion of subtropical water masses originates or recirculates into other basins as part of a Southern Hemisphere supergyre (Fratantoni et al., 2000; Laurian \& Drijfhout, 2011; Speich et al., 2007). According to Gordon et al. (1992) and most recent literature (e.g., Speich et al., 2007), a major proportion of the surface and central water masses that end up in the Benguela Current and SEC are first carried to the Indian Ocean through the South Atlantic Current and then recirculate back via the Agulhas Current past South Africa. Some of the deeper AAIW that eventually becomes part of the AMOC recirculates even further east into the Pacific basin (Speich et al., 2007).

Our goal is to expand our knowledge on the interconnections between the subtropical and tropical gyres in the South Atlantic down to a depth of $1,500 \mathrm{~m}$, which includes all surface, central, and intermediate water masses. For this purpose, we use the hydrographic and velocity fields from GLORYS2V4, an eddy-permitting reanalysis model. From the release of particles along selected sections, we infer the predominant pathways and ages for water parcels transferring between the subtropical and tropical gyres as well as for water parcels recirculating within each gyre. In particular, we focus on the pathways followed by the subtropical water masses that reach the NBUC-what may be considered as the returning branch of the AMOC in the South Atlantic-and investigate the mechanisms responsible for the associated changes in heat and freshwater transports.

The structure of the article is as follows. In section 2 we introduce the data and methods, and in section 3 we present the pathways and the heat and salt transports associated with the different water masses. We conclude in section 4 with a discussion of the new perspectives brought about by the Lagrangian approach and of the mechanisms necessary to produce the observed changes in heat and salt transport.

\section{Materials and Methods}

\subsection{Reanalysis Model GLORYS2V4}

The Mercator Ocean team computed and provided monthly-averaged values from the reanalysis model GLORYS2V4 (eddy-permitting with $\cong 0.25^{\circ}$ resolution; CMEMS, 2017). The monthly climatology includes values of salinity, temperature, and the three-dimensional velocity field, as calculated using the 23-year data set (1993 to 2015). Our region of study is the South Atlantic Ocean between $30^{\circ} \mathrm{S}$ and $5^{\circ} \mathrm{S}$ and down to 1,500 $\mathrm{m}$. The position of the northern and southern boundaries ensures that the entire subtropical-tropical boundary is contained in the domain and further warrants that the particles circulate only once through either the subtropical or the tropical gyre before leaving the domain.

Mignac et al. (2018) have recently performed an exhaustive comparison between current data assimilation products (including GLORYS2V4), free-running models, and observations. This comparison shows that the reanalysis products are more accurate than the free-running models at representing the AMOC's strength and meridional heat transport at $35^{\circ} \mathrm{S}$ and the NBUC volume transport at $11^{\circ} \mathrm{S}$. Although the heat and volume transports are systematically underestimated across models, GLORYS2V4 is the one that shows the highest agreement with observations (Mignac et al., 2018). Drijfhout et al. (2003) have also found that eddy-permitting models are essential to correctly represent the Lagrangian pathways in the thermocline. These results endorse the idea that GLORYS2V4 will be a very valuable tool for examining the exchange of subtropical and tropical waters in the South Atlantic Ocean; further information on the model's performance can be found in von Schuckmann et al. (2016).

\subsection{Lagrangian Experiments}

We use the Connectivity Modeling System code v2.0 (Paris et al., 2013) to track $~ 10,000$ particles pathways offline. The inputs for this code are the time-varying horizontal $(u, v)$ and vertical $w$ velocity component fields and fixed values for the horizontal $\left(k_{\mathrm{h}}\right)$ and vertical $\left(k_{\mathrm{v}}\right)$ diffusion coefficients. We choose two latitudinal sections near the western boundary (black lines in Figure 1a) where we release the particles and trace their trajectories back in time to study the transport between the subtropical and tropical gyres.

1. Section $8^{\circ} \mathrm{S}$ experiment traces back the northward flow at $8^{\circ} \mathrm{S}$ in the upper 1,400 -m layer, between the South American coast and $15^{\circ} \mathrm{W}$ (Figure 1d). This experiment is designed to include both the NBUC, 

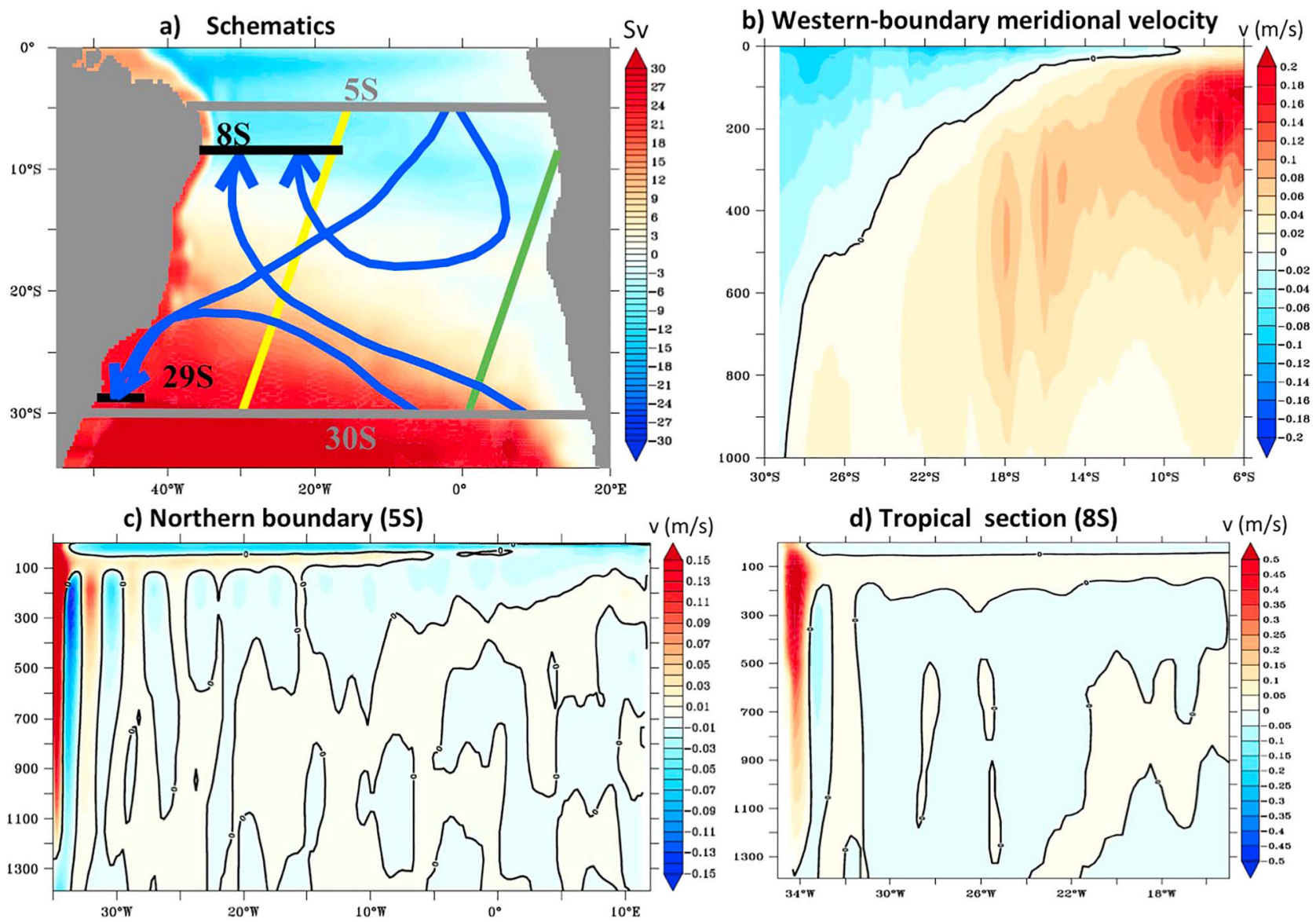

e) Southern boundary (30S)
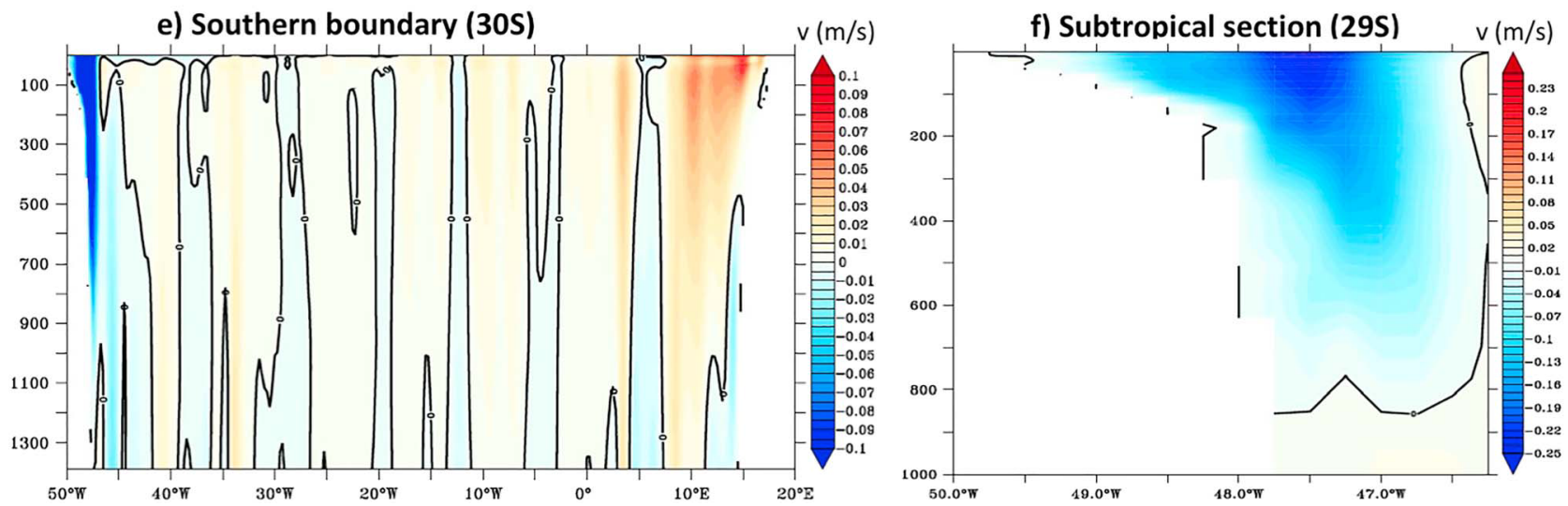

Figure 1. (a) Meridional transport (Sv) in the top 1,500 m, accumulated from the eastern boundary, as obtained from climatological averaged meridional velocities. The experiment release sections are shown in black, the northern and southern boundary sections in gray, and the schematic representations of the four possible trajectories in blue. Two sections approximately perpendicular to the main flow are shown in yellow (western) and green (eastern). (b) Western-boundary meridional velocity, averaged within a $2.5^{\circ}$ band off the coast $(\mathrm{m} / \mathrm{s})$ as a function of depth $(\mathrm{m})$ and latitude. Meridional velocity (m/s) depth-longitude profile at (c) the northern boundary $\left(5^{\circ} \mathrm{S}\right)$, (d) the $8^{\circ} \mathrm{S}$ release section, (e) the southern boundary $\left(30^{\circ} \mathrm{S}\right)$, and (f) the $29^{\circ} \mathrm{S}$ release section.

which is located between the continental slope and about $32.5^{\circ} \mathrm{W}$, and the northward thermocline transport (50-200 $\mathrm{m}$ ) found in the interior ocean as far as $15^{\circ} \mathrm{W}$.

2. Section $29^{\circ} \mathrm{S}$ experiment traces back the southward flow at $29^{\circ} \mathrm{S}$ in the upper 1,000-m layer, between the coastline of South America and $46^{\circ} \mathrm{W}$ (Figure 1f). This experiment is designed to track the BC, isolated from the deeper northward countercurrent and from the deeper southward deep western boundary current. 
The number of particles $N$ released at each pixel (lon, depth) is set to be proportional to the meridional transport at that location, $v A$ (where $v$ is the meridional velocity and $A$ is the vertical area of the pixel, $\Delta$ lon $\Delta$ depth), that is, more particles are released wherever and whenever the meridional transport is higher. This way, each particle carries the same water transport $(\nu A / N)$, which optimizes the sampling and facilitates the calculation of Lagrangian streamlines.

Our focus is on the climatological and year-averaged velocities, hence leaving aside the impact of interannual variations. The difference between both cases will reveal the role of seasonality on the net transfer of water between the tropical and subtropical gyres. We use the monthly-averaged velocity and density data interpolated every 3 days, as several tests show that the trajectories are fairly insensitive to a higher temporal resolution while a lower resolution causes some significant differences in the fast-current regions (not shown).

The model is eddy-permitting but not entirely resolved, so the level of diffusion is probably underestimated (see a more detailed analysis of diffusion parameters in Peña-Izquierdo et al., 2015). We have studied the sensitivity of our results when the following diffusion parameters are added to the Lagrangian experiments: $k_{\mathrm{h}}=0,100,500,1,000 \mathrm{~m}^{2} / \mathrm{s}$, and $k_{\mathrm{v}}=0,10^{-5}, 10^{-6}, 10^{-7} \mathrm{~m}^{2} / \mathrm{s}$. We find that a value of $100 \mathrm{~m}^{2} / \mathrm{s}$ for horizontal diffusivity minimizes the number of particles that are lost near coastal regions or near the surface due to methodological limitations. This is also the preferred value in Peña-Izquierdo et al. (2015), who analyzed in detail the differences between horizontal diffusivity coefficients in the ECCO2 model, with the same horizontal resolution as GLORYS2V4. Changes in vertical diffusion do not affect our results significantly, so we set it to 0 for the final experiments. Importantly, our general conclusions remain the same when using a different set of diffusion parameters (see the sensitivity of the Lagrangian transports to a selected set of diffusion parameters in Table 1).

\subsection{Lagrangian Stream Function}

The Lagrangian stream function differs from the traditional Eulerian stream function because it only shows the transports associated to pathways that end up at the release section (Blanke et al., 1999, and references therein). The calculation is straightforward if we assume conservation of volume transport, which holds true if particles leave the studied domain. This is the case for our experiments, where nearly all released particles $(>97 \%)$ leave the domain in less than 50 years.

To calculate the Lagrangian stream function in the South Atlantic, we first define an output grid $\left(0.5^{\circ}\right.$ resolution) and evaluate, at each time step (backward in time) and for each particle, whether the particle has moved meridionally to a different output grid cell. If so, the initial meridional transport $(\nu A / N)$, positive for the $8^{\circ} \mathrm{S}$ experiment and negative for the $29^{\circ} \mathrm{S}$ experiment, is added to the intersection between cells (multiplied by -1 if northward, +1 if southward to account for backtracking of the particle trajectory). If more than one cell is crossed in a single time step, transport is added to each crossed intersection. Eventually, the particles leave the domain either through the northern or southern borders (Figures 1c and 1e). The meridional transport is cumulatively integrated with longitude (from the eastern side of the Atlantic) and results in our final Lagrangian stream function.

\subsection{Mass, Heat, and Salt Transport Calculation}

The total volume $V$ and mass $M$ transports $\left(\mathrm{m}^{3} / \mathrm{s}\right.$ and $\left.\mathrm{kg} / \mathrm{s}\right)$ are calculated as

$$
V=\sum_{i=1}^{N} V_{i}, \quad M=\sum_{i=1}^{N} \rho_{i} V_{i}
$$

where $V_{i}$ is the $i$ particle volume transport $\left(\mathrm{m}^{3} / \mathrm{s}\right)$ and $\rho_{i}$ the water density at the $i$ location. Volume transport is conserved by construction in our experiments, and mass transport is almost conserved because particles approximately follow constant density lines.

The total heat transport $H$ (in watts) across a section at any fixed latitude is calculated as

$$
H=c_{p} \sum_{i=1}^{N} \rho_{i} V_{i}\left(T_{i}-T_{r}\right),
$$

where $T_{i}$ is the particle potential temperature, $T_{r}$ is the reference temperature (set as $0{ }^{\circ} \mathrm{C}$ ), and $c_{p}$ is the sea water heat capacity $\left(c_{p}=3,985 \mathrm{Jkg}^{-1} \mathrm{~K}^{-1}\right)$. 
Table 1

Sensitivity of Experiments to a Selection of Horizontal and Vertical Diffusion Parameters $\left(\mathrm{m}^{2} / \mathrm{s}\right)$ and to the Use of Different Velocity Fields (Climatological CLIM Versus Year-Averaged $Y R-A V)$

\begin{tabular}{|c|c|c|c|c|c|c|c|}
\hline Section & Pathway & $\begin{array}{l}\text { CLIM } \\
k_{\mathrm{h}}=0 \\
k_{\mathrm{v}}=0\end{array}$ & $\begin{array}{c}\text { CLIM } \\
k_{\mathrm{h}}=100 \\
k_{\mathrm{v}}=0\end{array}$ & $\begin{array}{c}\text { CLIM } \\
k_{\mathrm{h}}=100 \\
k_{\mathrm{v}}=10^{-5}\end{array}$ & $\begin{array}{c}\text { CLIM } \\
k_{\mathrm{h}}=500 \\
k_{\mathrm{v}}=0\end{array}$ & $\begin{array}{c}\text { YR-AV } \\
k_{\mathrm{h}}=100 \\
k_{\mathrm{v}}=0\end{array}$ & $\begin{array}{c}\mathrm{YR}-\mathrm{AV} \\
k_{\mathrm{h}}=500 \\
k_{\mathrm{v}}=0\end{array}$ \\
\hline $8^{\circ} \mathrm{S}$ & $5^{\circ} \mathrm{S} \rightarrow 8^{\circ} \mathrm{S}$ & 12.9 & 13.3 & 13.1 & 14.0 & 13.1 & 13.6 \\
\hline \multirow[t]{2}{*}{$(38.5 \mathrm{~Sv})$} & $30^{\circ} \mathrm{S} \rightarrow 8^{\circ} \mathrm{S}$ & 21.9 & 22.3 & 22.4 & 23.1 & 22.4 & 23.4 \\
\hline & $z>1,500 \mathrm{~m} \rightarrow 8^{\circ} \mathrm{S}$ & 3.6 & 2.9 & 3.0 & 1.4 & 3.0 & 1.5 \\
\hline $29^{\circ} \mathrm{S}$ & $5^{\circ} \mathrm{S} \rightarrow 29^{\circ} \mathrm{S}$ & -1.5 & -1.4 & -1.5 & -1.6 & -1.6 & -1.6 \\
\hline$(-9.9 \mathrm{~Sv})$ & $30^{\circ} \mathrm{S} \rightarrow 29^{\circ} \mathrm{S}$ & -8.4 & -8.5 & -8.4 & -8.3 & -8.3 & -8.3 \\
\hline
\end{tabular}

Note. The table shows the water volume transport (Sv) associated to each Lagrangian experiment. The first column shows the collecting section (the meridional water transport is shown in parenthesis, with positive/negative values indicating northward/southward transports), the second column indicates the pathway, and the remaining columns quantify the associated northward/southward (positive/negative) transports.

The salt transport $S(\mathrm{~kg} / \mathrm{s})$ is calculated as

$$
S=\sum_{i=1}^{N} \rho_{i} S_{i} V_{i}
$$

where $S_{i}$ is the particle salinity (in units of kilogram salt per kilogram water). In this paper, the salt transport is also expressed in mass transport units (Sv), following Talley (2008) and using 35 as the average salinity,

$$
S=\sum_{i=1}^{N} \frac{S_{i}}{35} V_{i} .
$$

\subsection{Trajectory Clustering}

We also average the spatial trajectories (longitude, latitude, and depth) and properties (temperature, salinity, and density) for all the particles that belong to one same group. For example, in section 3.4 we consider all particles that belong to the same density bin (group) and combine the individual trajectories based on the fraction of distance traveled from the origin to the end section (after normalizing the traveled distance for each particle from 0 to 1). These results are not an exact representation of the real averaged trajectories but help visualize the differences between groups.

\section{Transfer of Water Masses Between the Tropical and Subtropical Gyres}

We can use the velocity fields at any time to calculate the instantaneous depth-integrated $(0-1,500 \mathrm{~m})$ Eulerian stream function. As for the Lagrangian streamlines, we do so by accumulating the meridional transport from the eastern side of the basin. Since we are not integrating the full water column, and there is a small fraction of water particles that upwells from deeper layers, the Eulerian transport is not strictly conserved. However, the nonconservative fraction is small so that the Eulerian stream function becomes a useful complementary tool.

The mean velocity fields (Figures 1b-1f), and the Eulerian (Figure 2e) and Lagrangian streamlines (Figures 2a-2d) reflect the existence of the western and eastern boundary currents. These boundary currents are identified as a connected region, adjacent to the continental slope, where the flow has one predominant direction. At the reference sections, they are located as follows: The NBUC is found west of $33.0^{\circ} \mathrm{W}$ at $5^{\circ} \mathrm{S}$ (Figure 1c) and west of $32.5^{\circ} \mathrm{W}$ at $8^{\circ} \mathrm{S}$ (Figure $1 \mathrm{~d}$ ), the $\mathrm{BC}$ is placed west of $46.2^{\circ} \mathrm{W}$ at $29^{\circ} \mathrm{S}$ (Figure 1f) and west of $47.0^{\circ} \mathrm{W}$ at $30^{\circ} \mathrm{S}$ (Figure 1e), and the Benguela Current is located east of $8.0^{\circ} \mathrm{E}$ at $30^{\circ} \mathrm{S}$ (Figure $1 \mathrm{e}$ ).

For our analysis we follow Ganachaud (2003) and Talley (2003) and split the particles among surface and near-surface, central, and intermediate layers, considering their initial or final vertical location; along their trajectory, particles often change greatly their location in the water column (Table 2). The surface particles occupy roughly the upper $60 \mathrm{~m}$ of the water column (potential density $\sigma_{0}$ less than about $25.0 / 25.5 \mathrm{~kg} / \mathrm{m}^{3}$ in the western/eastern basins), and the near-surface particles are found immediately below, down to some 
a) Subtropics to tropics (30,

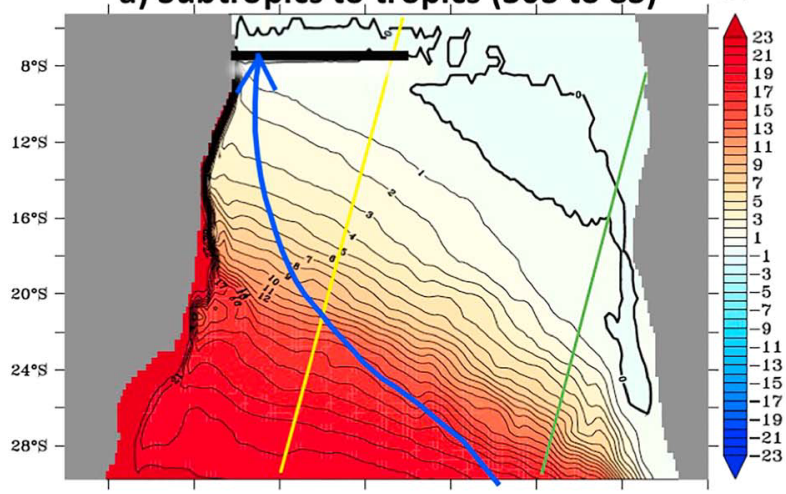

b) Tropical recirculation ( $5 S$ to $8 S$ )

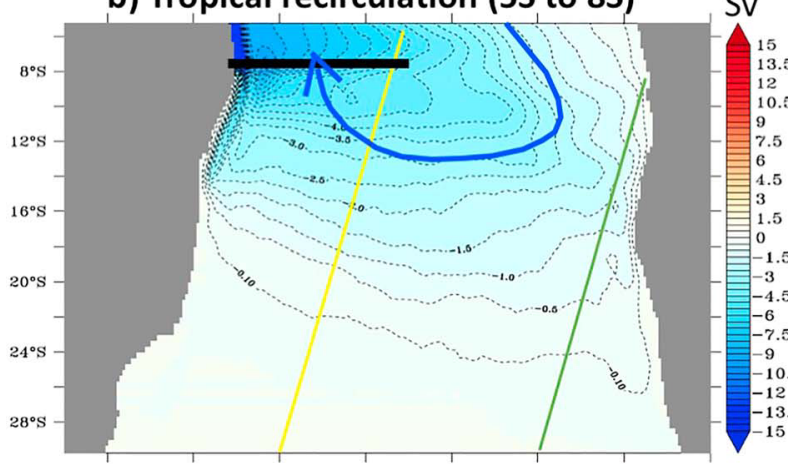

c) Subtropical arrival section (29S)

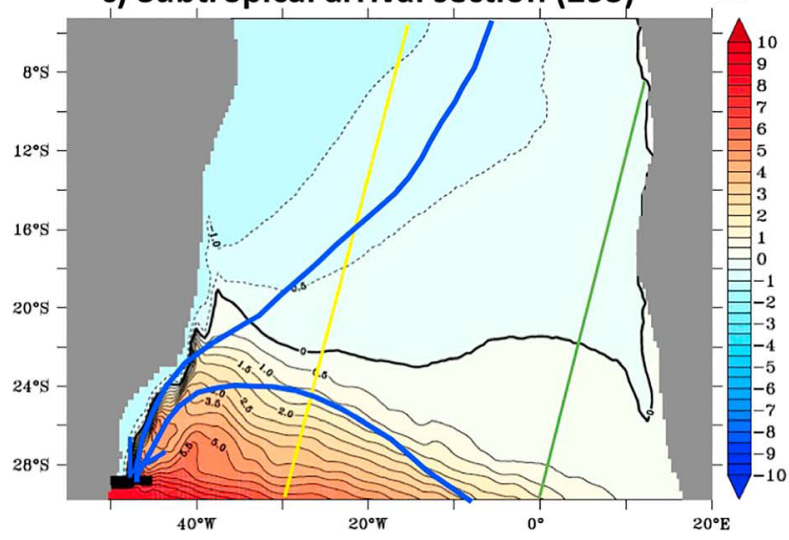

d) Sum of lagrangian streamfunctions

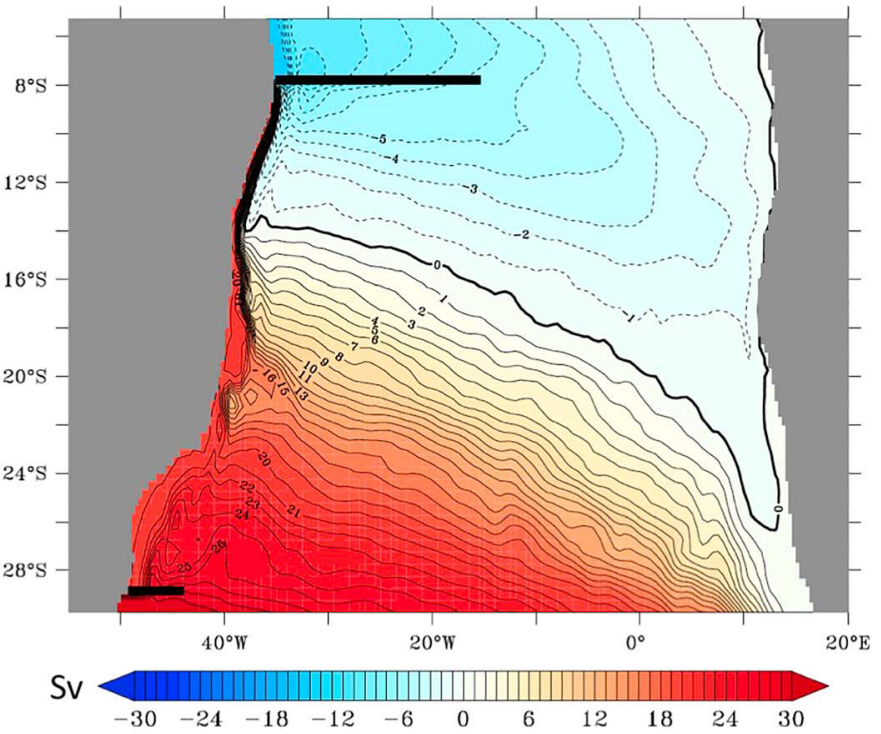

e) Eulerian streamfunction (to $1500 \mathrm{~m}$ )

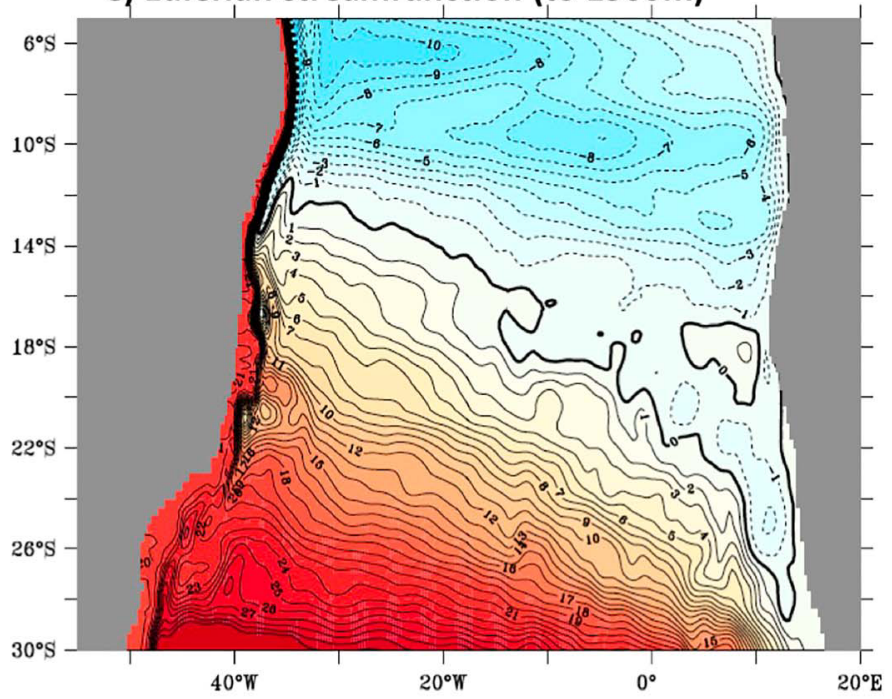

Figure 2. Lagrangian streamlines (Sv) for particles that (a) transfer from $30^{\circ} \mathrm{S}$ to $8^{\circ} \mathrm{S}$, (b) transfer from $5^{\circ} \mathrm{S}$ to $8^{\circ} \mathrm{S}$, and (c) end at the subtropical $29^{\circ} \mathrm{S}$ section. The release sections are shown in black, the two sections perpendicular to the main flow are shown in yellow and green as in Figure 1a, and the schematic of the trajectories are shown in blue. The sum of the four Lagrangian streamlines is shown in (d). The Eulerian stream function down to a depth of $1,500 \mathrm{~m}$ is shown in (e) for comparison.

100-200 $\mathrm{m}\left(\sigma_{0}\right.$ up to $\left.26.0 \mathrm{~kg} / \mathrm{m}^{3}\right)$. The central layers correspond to the Subtropical Mode Waters, corresponding to thermocline waters reaching down to less than $600 \mathrm{~m}\left(\sigma_{0}\right.$ from 26.0 to $\left.26.8 \mathrm{~kg} / \mathrm{m}^{3}\right)$. The intermediate layers travel at depths of roughly 500-1,500 m, including both Subantarctic Mode Water (SAMW, with $\sigma_{0}$ from 26.8 to $27.2 \mathrm{~kg} / \mathrm{m}^{3}$ ) and AAIW ( $\sigma_{0}$ from 26.8 to $27.55 \mathrm{~kg} / \mathrm{m}^{3}$ ).

The main objective of the forthcoming discussion is to understand and quantify the four possible pathways for water departing in the tropical/subtropical gyres and ending at the NBUC and BC: the subtropical and tropical recirculations and the exchange between the tropical and subtropical gyres (blue trajectories in Figure 1a). Throughout this paper, we will refer to those water masses transferred from the subtropical to the tropical gyre as AMOC water masses. 
Table 2

The Average Depths at Which the Given Water Masses (Left Column) Reach Their Maximal Potential Density Value $\sigma_{0}$ for the Different Latitudinal Sections; This Also Includes the Dependence With Longitude

\begin{tabular}{lcrrrrrr}
\hline Water mass & \multicolumn{7}{c}{ Depth $(\mathrm{m})$} \\
\cline { 3 - 8 } & $\begin{array}{c}\sigma_{0} \max \\
\left(\mathrm{kg} / \mathrm{m}^{3}\right)\end{array}$ & $\begin{array}{c}8^{\circ} \mathrm{S} \\
\text { section }\end{array}$ & $\begin{array}{c}29^{\circ} \mathrm{S} \\
\text { section }\end{array}$ & $\begin{array}{c}5^{\circ} \mathrm{S} \\
\text { west of } 0^{\circ} \mathrm{E}\end{array}$ & $\begin{array}{c}5^{\circ} \mathrm{S} \\
\text { east of } 0^{\circ} \mathrm{E}\end{array}$ & $\begin{array}{c}30^{\circ} \mathrm{S} \\
\text { west of } 8^{\circ} \mathrm{E}\end{array}$ & $\begin{array}{c}30^{\circ} \mathrm{S} \\
\text { east of } 8^{\circ} \mathrm{E}\end{array}$ \\
\hline Surface & 25 & 104 & 13 & 82 & 35 & 25 & - \\
Near surface & 26 & 148 & 203 & 111 & 79 & 162 & 103 \\
Central & 26.8 & 306 & 578 & 339 & 364 & 590 & 456 \\
Intermediate & 27.2 & 848 & 1,080 & 837 & 831 & 1,096 & 906 \\
& 27.55 & 1,390 & 1,765 & 1,371 & 1,372 & 1,712 & 1,510 \\
\hline
\end{tabular}

\subsection{Velocity Fields and Water Masses}

The boundary current system off the eastern coast of South America (Figure 1b) is similar to the one simulated by Rodrigues et al. (2007), who studied in detail the bifurcation between northward and southward currents at the western boundary. The western boundary currents at $5^{\circ} \mathrm{S}$ and $11^{\circ} \mathrm{S}$ are consistent with Schott et al. (2005) and Hummels et al. (2015) observations, both in terms of depth structure and volume transports. Further, the southward deepening and strengthening of the BC in GLORYS2V4 approximately coincides with real estimates obtained from moorings in Rocha et al. (2014). They find $5.7 \mathrm{~Sv}$ at $25^{\circ} \mathrm{S}$ (mooring C3, July and August) and $10.0 \mathrm{~Sv}$ at $28^{\circ} \mathrm{S}$ (mooring W333, December and January), while we respectively find 5.1 and 10.4 Sv when considering the same sampling periods.

Figure 3 shows the spatial distribution of the different water masses when crossing the South Atlantic westward through oblique sections centered at $25^{\circ} \mathrm{W}$ and $5^{\circ} \mathrm{E}$ (hereafter western and eastern sections; yellow and green lines in Figure 1a, respectively). Consider first the eastern section, which is clearly dominated by the subtropical pathways to the tropics $\left(30^{\circ} \mathrm{S}\right.$ to $8^{\circ} \mathrm{S}$, AMOC water; Figure $2 \mathrm{a}$ and red dots in Figure $3 \mathrm{~b}$ ); these water masses account for most of the transport to the northwest (18 Sv), while subtropical recirculating water masses represent only $1.5 \mathrm{~Sv}$. The subtropical recirculation takes place further south and shallower than the AMOC water, its surface layers reaching only as far north as about $20^{\circ} \mathrm{S}$ (orange dots in Figure $3 \mathrm{~b}$ ). We find that the direction of the velocity at $30^{\circ} \mathrm{S}$ determines whether the particle will continue to the north or will recirculate within the subtropical gyre: The more northward the velocity at $30^{\circ} \mathrm{S}$, the more likely it will leave the subtropical gyre and reach $8^{\circ} \mathrm{S}$ (not shown).
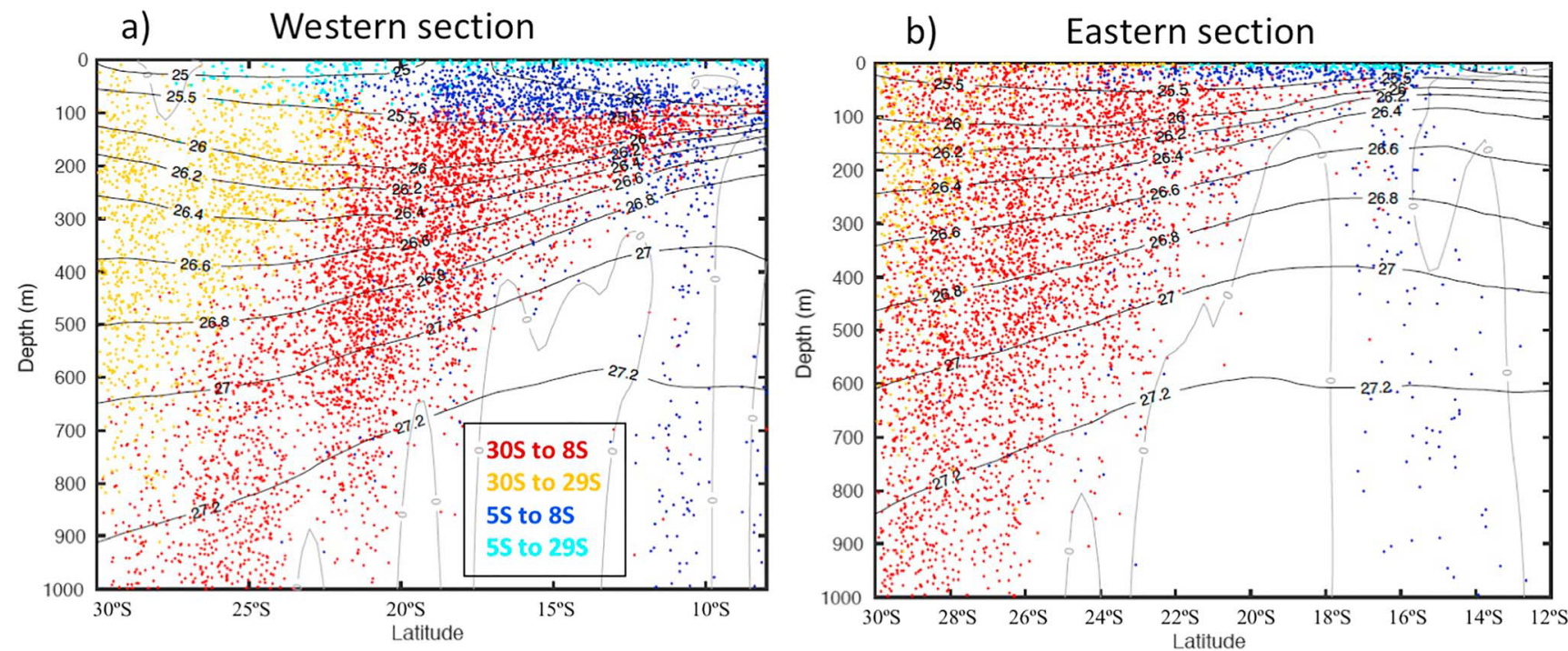

Figure 3. Depth-latitude distribution of particles flowing west in the (a) western and (b) eastern cross sections of Figure 1a, colored by the water route as labeled. The black lines show the potential density contours $\left(\sigma_{0}\right)$, and the gray line shows the zero zonal velocity contour. 
Only a small fraction of tropical recirculating water masses (1.1 Sv) reach the eastern section (blue dots in Figure 3b). These water masses flow either (a) within the surface (upper $50 \mathrm{~m}$ ), on top of AMOC water masses $(0.3 \mathrm{~Sv})$ and interacting with surface recirculating subtropical water masses from $24^{\circ} \mathrm{S}$ to $21^{\circ} \mathrm{S}$, (b) at similar depths as AMOC water $(0.2 \mathrm{~Sv})$, or (c) through deep zonal jets at $\cong 15-17^{\circ} \mathrm{S}$ that do not interact with AMOC water $(0.6 \mathrm{~Sv})$.

Consider now the western section where all four pathways are clearly separated (Figure 3a). The VitóriaTrindade Ridge, which along this section is located at $21^{\circ} \mathrm{S}$, defines the near-surface bifurcation latitude between the subtropical gyre $(5.5 \mathrm{~Sv})$ and the AMOC water mass $(21.8 \mathrm{~Sv})$, in agreement with Soutelino et al. (2013). The bifurcation latitude shifts south with depth (see also black line in Figure 1b). Note that the subtropical gyre penetrates to the intermediate layers (Figure 3a), in agreement with results by Schmid et al. (2000). Moreover, this western section clearly illustrates that the entire AMOC transfer, from the subtropics $\left(30^{\circ} \mathrm{S}\right)$ to the tropics $\left(8^{\circ} \mathrm{S}\right)$, occurs mainly within central and intermediate layers.

The transport of recirculating tropical water masses that reach the western section equals $3.9 \mathrm{~Sv}$, with about half arriving directly from $5^{\circ} \mathrm{S}$ and the other half after having transited southeast into the Angola Dome (Figure 2b), returning west partly as deep zonal jets along $10-12^{\circ} \mathrm{S}(1.0 \mathrm{~Sv}$; blue dots in Figure $3 \mathrm{a})$. The tropical water masses that are transferred to the subtropics (1.4 Sv) flow on top of the recirculating tropical water masses (cyan dots in Figure 3a) and eventually fill the surface part of the southward flow in the western boundary (Figure 1b).

\subsection{Transport at the Tropical $8^{\circ} \mathrm{S}$ Section}

A total of $38.5 \mathrm{~Sv}$ follow north through the $8^{\circ} \mathrm{S}$ section, with most of it (35.0 Sv) occurring at all depths within the NBUC and a small fraction (3.5 Sv) flowing through the interior thermocline near the surface (50-150 $\mathrm{m}$ ). The origins of this northward current are shown in Figure 4a. Most of it, $22.3 \mathrm{~Sv}$ (58\% of the total volume transport), enter the domain in the subtropics $\left(30^{\circ} \mathrm{S}\right.$, black dots and contours in Figure $\left.4 \mathrm{a}\right)$. These subtropical water masses feed the core of the NBUC (21.4 Sv at depths 100 to 1,200 m) and the near-surface interior layers $(0.9 \mathrm{~Sv}$ at depths 50 to $150 \mathrm{~m})$. The $8^{\circ} \mathrm{S}$ current also transports $13.3 \mathrm{~Sv}$ of tropical origin $(34.5 \%$ of the total volume transport), feeding the surface $(3.8 \mathrm{~Sv})$ and eastern edge $(6.2 \mathrm{~Sv})$ layers of the NBUC, the central and intermediate layers near $32^{\circ} \mathrm{W}$ ( $1 \mathrm{~Sv}$ at depths 200 to $1,000 \mathrm{~m}$ ), and the near-surface $(50-150$ $\mathrm{m})$ interior flow as far as $15^{\circ} \mathrm{W}(1.8 \mathrm{~Sv}$; red dots and contours in Figure $4 \mathrm{a})$. The remaining fraction of the NBUC (2.8 Sv, 7\%) originates below 1,500 $\mathrm{m}$ in the subtropics (green dots in Figure 4a).

As noted in the methods section, the results are qualitatively similar when using different diffusivities (Table 1). However, as the horizontal diffusivity increases, the border between the tropical and subtropical Lagrangian streamlines diffuses and the number of particles originating deeper than 1,500 m decreases (not shown).

\subsubsection{Subtropical to Tropical Transfer $\left(30^{\circ} \mathrm{S}\right.$ to $\left.8^{\circ} \mathrm{S}\right)$}

Most of the water of subtropical origin (originating at $30^{\circ} \mathrm{S}$ ) that ends in the NBUC at $8^{\circ} \mathrm{S}$ comes from the deep flow (down to $\cong 1,500 \mathrm{~m}$ ) in the eastern basin (east of $8^{\circ} \mathrm{E}$ ) at $30^{\circ} \mathrm{S}(14.9 \mathrm{~Sv}$; black dots in Figure $4 \mathrm{c}$ ). This flow constitutes the core of the returning limb of the AMOC, arriving mainly from the Indian Ocean via Agulhas rings and filaments (e.g., Donners \& Drijfhout, 2004; Gordon et al., 1992; Speich et al., 2007). Finding the exact origin of this northward flow at $30^{\circ} \mathrm{S}$ would require running the Lagrangian experiments over a much larger domain, which is beyond the scope of this paper.

Interior water masses (departing west of $8^{\circ} \mathrm{E}$ at $30^{\circ} \mathrm{S}$ ) also reach $8^{\circ} \mathrm{S}$ along the intermediate layers, carrying a total of 7.4 Sv. In particular, we find that $6 \mathrm{~Sv}$ of these intermediate water masses are transported at $\sigma_{0}>27$ $\mathrm{kg} / \mathrm{m}^{3}$, comparable to the $4 \mathrm{~Sv}$ reported by Boebel et al. (1999) or the $5 \mathrm{~Sv}$ by Schmid et al. (2000) at the same densities. These water masses bifurcate around $28^{\circ} \mathrm{S}$ in the western boundary, at a location known as the Santos bifurcation (Boebel et al., 1999; Stramma \& England, 1999).

Figure 2a shows the Lagrangian streamlines for water masses that transfer from $30^{\circ} \mathrm{S}$ to $8^{\circ} \mathrm{S}$. In general, these water masses flow northwestward along a wide band from the eastern side at $30^{\circ} \mathrm{S}$ to the western boundary where they feed into the northward boundary current. Those water masses that reach the western boundary at the northern latitudes cross the South Atlantic more to the north (Figure 2a) and come from the subsurface eastern boundary at $30^{\circ} \mathrm{S}\left(25.5<\sigma_{0}<26.5 \mathrm{~kg} / \mathrm{m}^{3}\right.$; blue and green dots in Figure $\left.5 \mathrm{a}\right)$, while water masses originating more to the west and deeper at $30^{\circ} \mathrm{S}$ flow more directly westward and arrive to the western boundary 

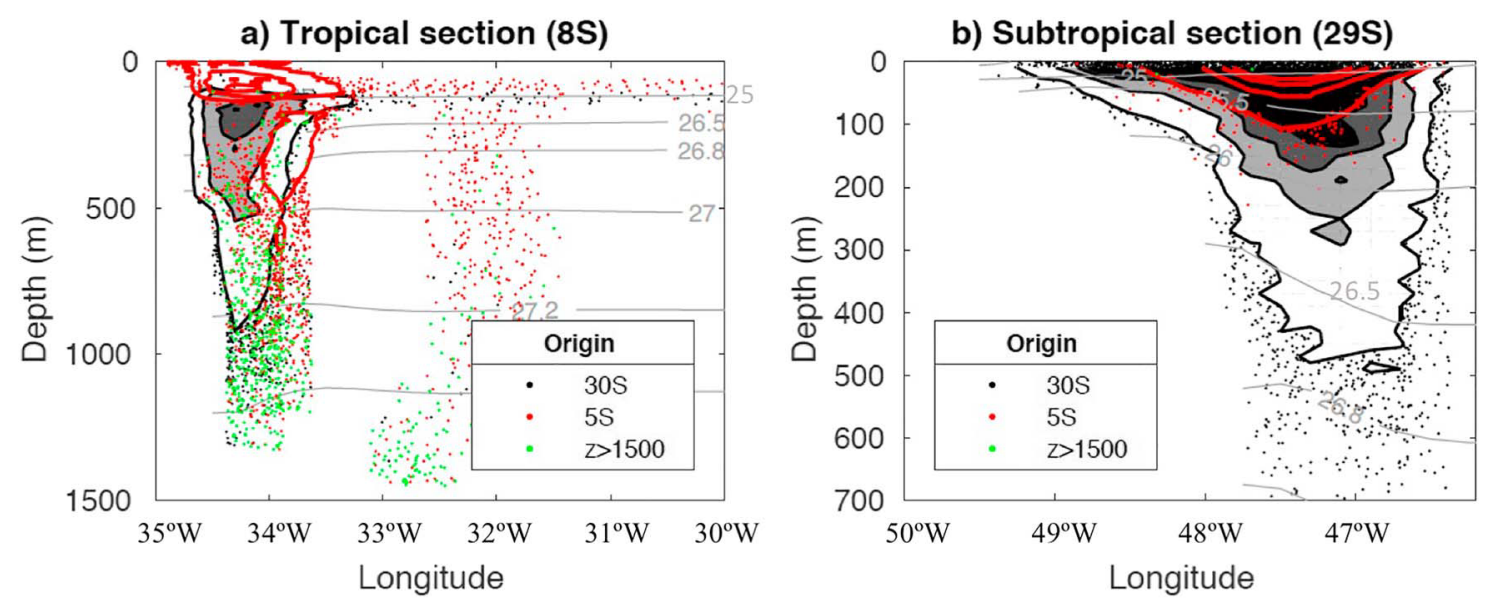

c) Southern boundary (30S)
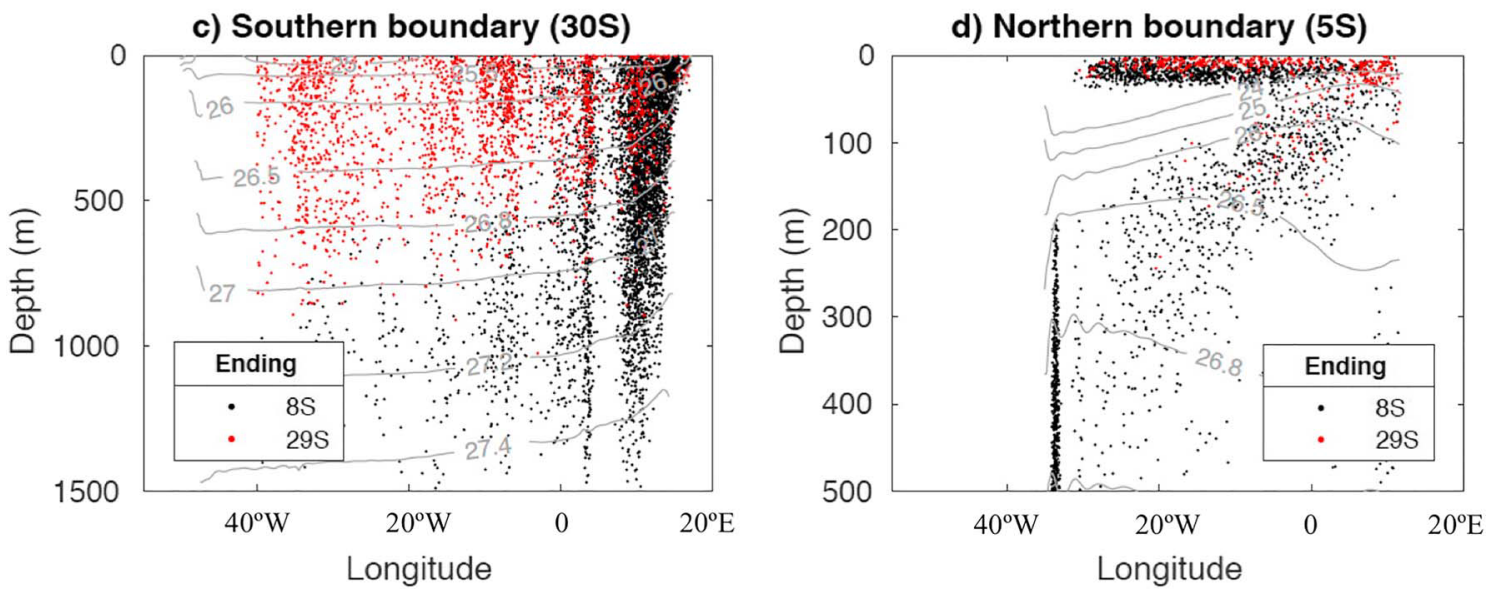

Figure 4. Spatial distribution of particles at (a) the tropical section $\left(8^{\circ} \mathrm{S}\right),(\mathrm{b})$ the subtropical section $\left(29^{\circ} \mathrm{S}\right)$, (c) the southern boundary $\left(30^{\circ} \mathrm{S}\right)$, and $(\mathrm{d})$ the northern boundary $\left(5^{\circ} \mathrm{S}\right)$, colored depending on the origin and ending as labeled. In (a) and (b), for the sake of clarity, the colored dots are replaced by contour lines wherever the number of particles is large $\left(>10,25,60\right.$, and 80 particles in pixels of size $\left.0.2^{\circ} \times 20 \mathrm{~m}\right)$. The potential density lines $\left(\sigma_{0}\right)$ are shown in gray.
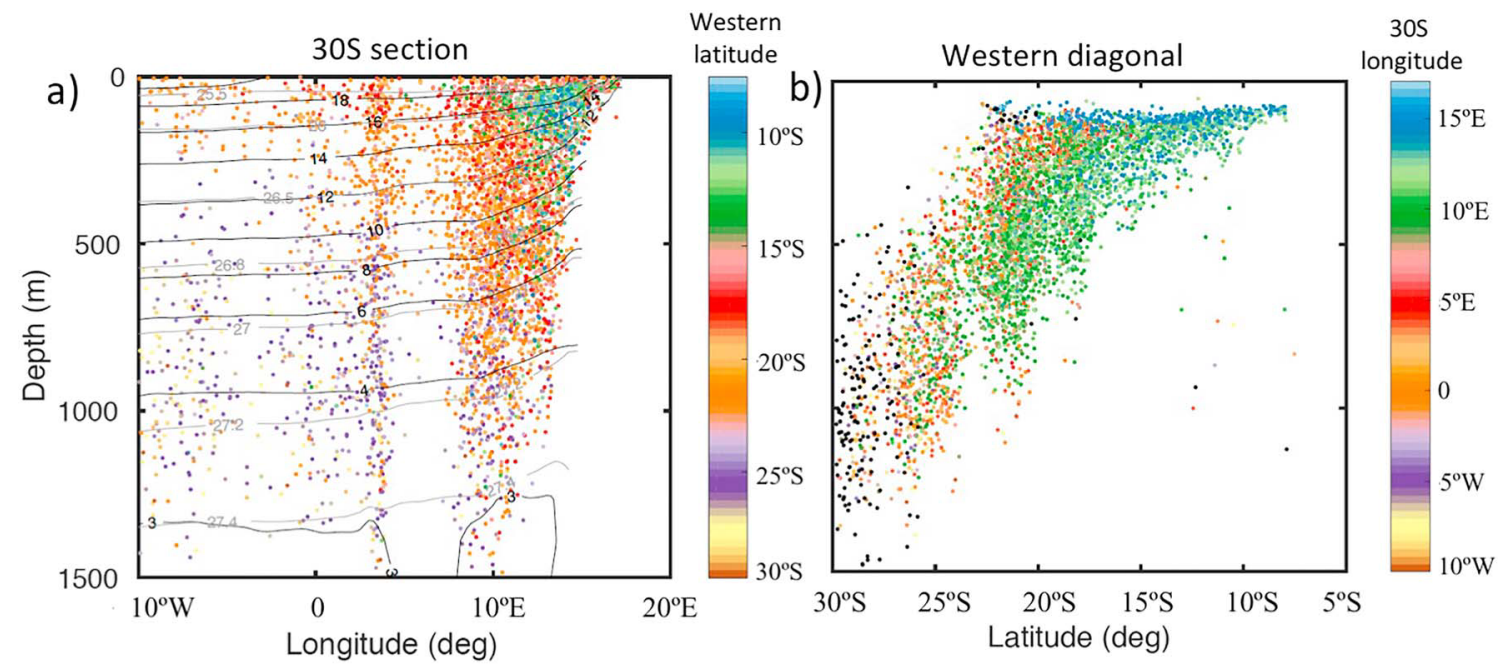

Figure 5. (a) Depth-longitude distribution in the eastern margin of $30^{\circ} \mathrm{S}$ for AMOC particles transferred from $30^{\circ} \mathrm{S}$ to $8^{\circ} \mathrm{S}$, colored by the latitude crossing the western section (yellow line in Figure 1a), with density and temperature contours overplotted in gray and black, respectively. (b) Depth-latitude distribution along the western section for AMOC particles, colored by their longitude at the southern boundary $\left(30^{\circ} \mathrm{S}\right)$. In both panels, black colored dots show data outside the longitudes or latitudes in the color bars. 
further south (Figure 5a). Another way of understanding the large spatial range of the South Atlantic northwestward subtropical-to-tropical transfer is through a latitude-depth distribution of particles through the western-basin section (which is roughly perpendicular to the main flow, yellow line in Figure 1a), illustrating the departing longitude at $30^{\circ} \mathrm{S}$ (Figure $5 \mathrm{~b}$ ). The deeper the transfer, the further south it occurs, in agreement with Stramma and England (1999). At any depth, the westward transfer occurs over a latitudinal band about $10^{\circ}$ wide, the latitude of transfer varying both with depth and with the original longitude at $30^{\circ} \mathrm{S}$.

Crossing the South Atlantic from $30^{\circ} \mathrm{S}$ to $8^{\circ} \mathrm{S}$ takes 8.9 years on average, with a long tail in the distribution and the $20 \%$ slowest particles taking over 21.2 years to cross (dark red line in Figure 6a). On average it takes 4.7 years for the surface and near-surface particles, 6.2 years for the central water masses, and 12.8 years for the intermediate water masses (Figure 6b). Lazar et al. (2001) found timescales of 5-6 years for anomalies propagating through the thermocline from $30^{\circ} \mathrm{S}$ to the equator, in good agreement with our results.

3.2.2. Tropical Recirculation $\left(5^{\circ} \mathrm{S}\right.$ to $\left.8^{\circ} \mathrm{S}\right)$

The tropical water masses (originating at $5^{\circ} \mathrm{S}$, Figure 1c) that end up northward at $8^{\circ} \mathrm{S}$ (red dots in Figure 4a) come either from the surface $(20-60 \mathrm{~m})$ throughout the entire $5^{\circ} \mathrm{S}$ section $(4.6 \mathrm{~Sv})$, from the near-surface and upper-thermocline layers $\left(4.0 \mathrm{~Sv}\right.$ east of $\left.32^{\circ} \mathrm{W}\right)$ or from the intermediate western boundary layers $(4.6 \mathrm{~Sv}$ west of $32^{\circ} \mathrm{W}$; black dots in Figure $\left.4 \mathrm{~d}\right)$.

At $5^{\circ} \mathrm{S}$, the surface waters $(4.6 \mathrm{~Sv})$ flow southwest before turning north along the western boundary (Figure $2 \mathrm{~b}$ ), on average taking 2.6 years to get to $8^{\circ} \mathrm{S}$ (yellow line in Figure 6c). Of these, many particles $(40 \%, 1.9 \mathrm{~Sv})$ recirculate along the surface but $60 \%$ (2.7 Sv) escape from the surface winter mixed layer depth, constituting the STC. About 1.1 Sv of these STC subsurface water masses flow along the upper-thermocline, and the remaining $0.7 \mathrm{~Sv}$ reach much deeper, in the intermediate levels. We observe that the STC water remains largely separated from the AMOC water masses, in agreement with Hazeleger \& Drifjhout (2006), who found that STC water masses feed the surface part of the northward current at $6^{\circ}$ and $10^{\circ} \mathrm{S}$ while AMOC water masses feed the subsurface part of the current $(>100 \mathrm{~m})$.

The water masses that originate below the thermocline at $5^{\circ} \mathrm{S}(4.0 \mathrm{~Sv})$ move preferentially toward the southeast before winding west and northwest along the western boundary (Figure 2b), in agreement with Hazeleger \& Drifjhout (2006). These water masses end up at surface and near surface at $8^{\circ} \mathrm{S}$ (red dots in Figure 4a), mostly above AMOC water masses (black dots in Figure 4a), taking on average 14.1 years to flow from $5^{\circ} \mathrm{S}$ to $8^{\circ} \mathrm{S}$, the traveling time increasing with depth (purple line in Figure 6c).

Finally, there is a tight recirculation of deep central and intermediate water near the western boundary (western black dots in Figure 4d), with 4.6 Sv of water flowing south off the boundary current and recirculating northward at $8^{\circ} \mathrm{S}$ (red dots and contours east of the core NBUC in Figure 4a). These water masses take on average 5.1 years to flow from $5^{\circ} \mathrm{S}$ to $8^{\circ} \mathrm{S}$, the longer, the deeper in the water column they are (orange line in Figure 6c).

\subsubsection{Comparison With Literature}

Hazeleger \& Drifjhout (2006) found 16 Sv of AMOC transport using a simulation with the same horizontal resolution as ours $\left(0.25^{\circ}\right)$. They found that around one third of the AMOC water upwells in the tropics and part of it $(2 \mathrm{~Sv})$ recirculates into the STCs before continuing northward. We find a similar amount of STC water masses $(2.7 \mathrm{~Sv})$ in our experiments.

Blanke et al. (1999) studied the transport of water from $10^{\circ} \mathrm{S}$ to $10^{\circ} \mathrm{N}$, down to a depth of $1,200 \mathrm{~m}$, with a lowresolution simulation ( $2^{\circ}$ zonal and $0.5-1.5^{\circ}$ meridional). They found $37.3 \mathrm{~Sv}$ of volume transport flowing northward at $10^{\circ} \mathrm{S}$, mostly through the western boundary, similar to our $38.5 \mathrm{~Sv}$ at $8^{\circ} \mathrm{S}$ (down to $1,500 \mathrm{~m}$ ), with $17.4 \mathrm{~Sv}$ reaching all the way to $10^{\circ} \mathrm{N}$. This interhemispheric handover, which is mainly associated to the AMOC, is comparable but less than the transfer we find from $30^{\circ} \mathrm{S}$ to $8^{\circ} \mathrm{S}: 14.9 \mathrm{~Sv}$ through the eastern boundary (east of $8^{\circ} \mathrm{E}$ at $30^{\circ} \mathrm{S}, z=0-1,500 \mathrm{~m}$ ) and $7.4 \mathrm{~Sv}$ from intermediate layers (west of $8^{\circ} \mathrm{E}$ at $30^{\circ} \mathrm{S}, z$ $>700 \mathrm{~m})$.

The AMOC water masses continue into the North Atlantic subtropical gyre (out of our domain), either directly along the western boundary for the deep water masses $\left(<7^{\circ} \mathrm{C}\right.$; Blanke et al., 1999) or after meandering around the tropics multiple times for warmer particles (Blanke et al., 1999; Hazeleger \& Drifjhout, 2006). In particular, Blanke et al. (1999) found that $19.9 \mathrm{~Sv}$ (out of the $37.3 \mathrm{~Sv}$ northward transport at $10^{\circ} \mathrm{S}$ ) recirculate in the tropics and return back to $10^{\circ} \mathrm{S}$ without contributing to the interhemispheric transfer of heat. When comparing their results with ours, we deduce that their recirculating surface and upper- 

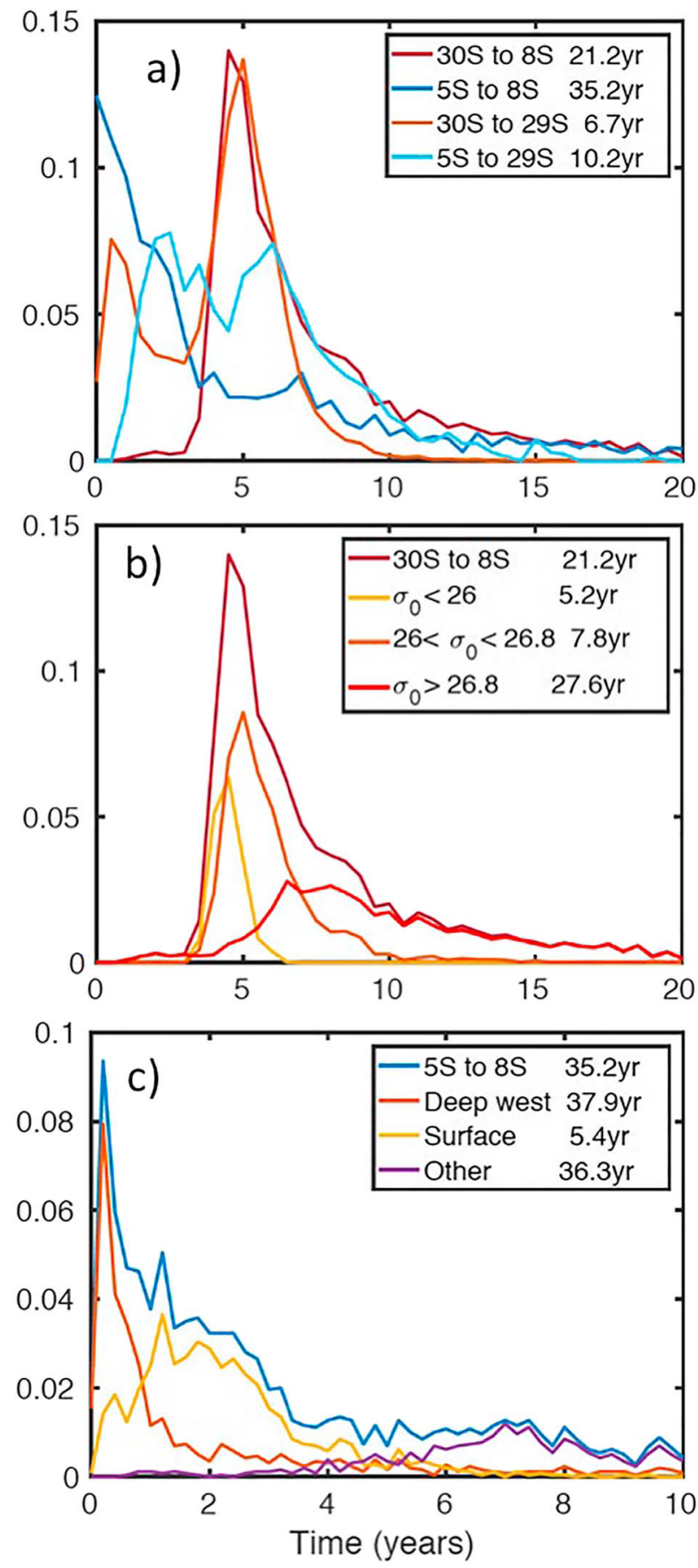

Figure 6. (a) Histograms showing the transfer time for the four different routes (arbitrarily normalized to a unit area), as labeled (bin width is 0.5 years). (b) Contributions of different density bins in the $30^{\circ} \mathrm{S}$ to $8^{\circ} \mathrm{S}$ course, as labeled. (c) Contributions of the different depth levels in the $5^{\circ} \mathrm{S}$ to $8^{\circ} \mathrm{S}$ course, as labeled (bin width is 0.2 years). The legend also shows the time that divides the $80 \%$ quickest particles from the $20 \%$ slowest particles. thermocline water coincides roughly with our southward surface tropical water at $5^{\circ} \mathrm{S}$. Blanke et al. (1999) also show that intermediate tropical water masses recirculate close to the western boundary, similarly to Schott et al. (2005) who observed this deep tight counterflow at $5-11^{\circ} \mathrm{S}$ with an associated transport (5 Sv) similar to our result (4.6 Sv).

\subsection{Transport at the Subtropical $29^{\circ} \mathrm{S}$ Section}

The southward western boundary BC carries a total of $9.9 \mathrm{~Sv}$ at $29^{\circ} \mathrm{S}$, split between $1.4 \mathrm{~Sv}$ at the surface and near-surface layers coming from the tropics (red dots and contours in Figure 4b), and 8.5 Sv at the upperthermocline layers coming from the subtropics (black dots and contours in Figure $4 \mathrm{~b}$ ). The subtropical water masses reaching $29^{\circ} \mathrm{S}$ originate mostly west of $8^{\circ} \mathrm{E}$ at $30^{\circ} \mathrm{S}$ (west of the AMOC eastern boundary flow) in the surface and central layers (red dots in Figure 4c), taking an average of 4.4 years (orange line in Figure $6 \mathrm{a}$ ). The tropical water masses transferring to $29^{\circ} \mathrm{S}$ come mainly from the surface $(1.0 \mathrm{~Sv})$ and near-surface $(0.4$ $\mathrm{Sv}$ ) layers at $5^{\circ} \mathrm{S}$ (red dots in Figure 4d); these water parcels on average take 5.8 years, the further west they start, the quicker the transfer (cyan in Figure 6a).

These results indicate that the timescale needed for thermocline particles to cross the South Atlantic is typically 5-10 years. This applies to the water parcels recirculating the tropical gyre (dark blue in Figure 6a), to those beginning at $30^{\circ} \mathrm{S}$ as part of the AMOC and arriving to $8^{\circ} \mathrm{S}$ (red in Figure 6a), and to the particles recirculating within the subtropics (orange in Figure 6a).

\subsection{Heat and Freshwater Transfer 3.4.1. AMOC Returning Water}

We first focus our analysis on the AMOC water (e.g., transfer from $30^{\circ} \mathrm{S}$ to $8^{\circ} \mathrm{S}$ in our experiment). The total heat transport at any latitude and longitude (cumulative with respect to the western boundary) is the sum of the conserved heat transport—calculated considering that the water particles maintain their $30^{\circ} \mathrm{S}$ original temperature along their trajectory (contour lines in Figure 7) - and the heat gain at any latitude as compared with $30^{\circ} \mathrm{S}$ (color shading in Figure 7). Water masses flowing from $30^{\circ} \mathrm{S}$ to $8^{\circ} \mathrm{S}$ transport $0.90 \mathrm{PW}$ of heat at $30^{\circ} \mathrm{S}$ and gain an additional $0.20 \mathrm{PW}$ along the South Atlantic, most of it $(0.15 \mathrm{PW})$ occurring gradually from $30^{\circ} \mathrm{S}$ to $18^{\circ} \mathrm{S}$. Water masses departing $30^{\circ} \mathrm{S}$ west of $8^{\circ} \mathrm{E}$ originally transport 0.64 PW and only warm by 0.02 PW (Table 3); in contrast, water masses departing east of this latitude initially only carry $0.26 \mathrm{PW}$ and warm by 0.18 PW (Table 3). After their incorporation into the western boundary, water masses actually cool slightly (0.01 PW). See Table 3 for a comparison among water masses.

Temperature and salinity increase toward the tropics up to $8^{\circ} \mathrm{S}$ along isopycnals and also toward the west for light water masses $\left(\sigma_{0}<26 \mathrm{~kg} / \mathrm{m}^{3}\right.$; not shown). Hence, as particles cross the South Atlantic approximately along isopycnals, we expect them to gain not only heat but also salt. In particular, subtropical $\left(30^{\circ} \mathrm{S}\right)$ water reaching $8^{\circ} \mathrm{S}$ gains $0.22 \mathrm{~Sv}$ of saltvolume transport (Table 3).

Within the central water stratum, temperature and salinity bear a linear relation, with both properties increasing toward the sea surface (light blue and green dots in Figure 8a; Poole and Tomczak, 1999). A scatter plot of temperature and salinity changes between $30^{\circ} \mathrm{S}$ and $8^{\circ} \mathrm{S}$ displays an approximate linear relation (Figure 8b). Since the slope of the central- 


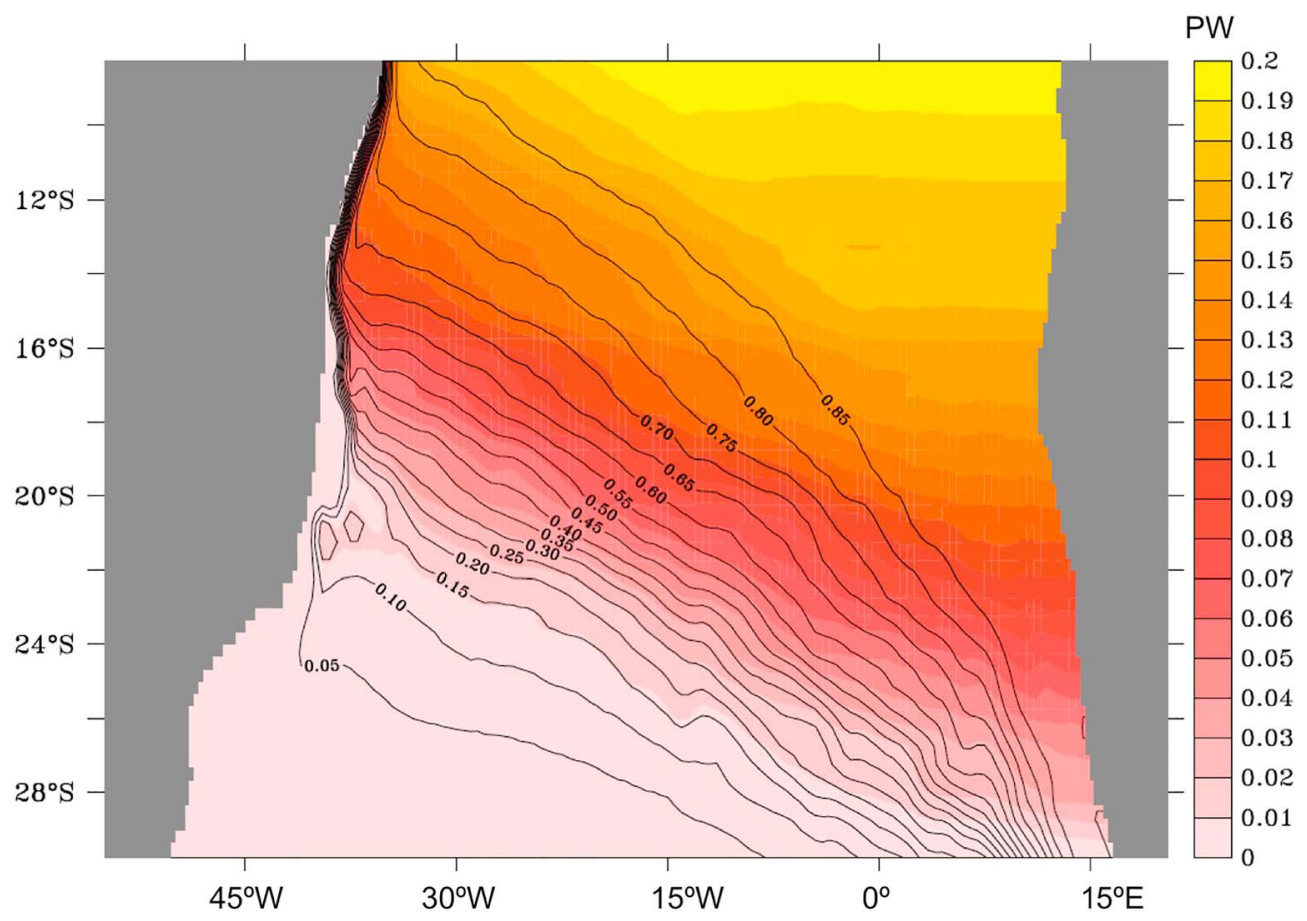

Figure 7. The color-filled contours show the northward heat transport (PW) that is gradually accumulated from the western and southern boundaries as particles increase their temperature while moving from $30^{\circ} \mathrm{S}$ to $8^{\circ} \mathrm{S}$. In contrast, the black solid contours show the conservative northward heat transport accumulated from the western boundary, calculated considering that the water particles maintain their $30^{\circ} \mathrm{S}$ original temperature along their trajectory.

water T-S relation is greater than the slope of the isopycnals (Figure 8a), we expect the particles to move toward lighter isopycnals to match the observed temperature and salinity increase (Figure 8b). Indeed, as particles flow north, the temperature increase overcompensates the salinity changes so that water masses gain some buoyancy (Figure 8c). However, we find that changes in density are relatively small when compared to changes in spiciness (Flament, 2002), showing that most of the diffusive and advective motions occur along quasi-isopycnals. We also find that, for the same change in temperature, surface

Table 3

The First Row Shows the $30^{\circ} \mathrm{S}$-to- $8^{\circ} \mathrm{S}$ Volume Transport, Total Heat Gain and Total Salinity Gain

\begin{tabular}{|c|c|c|c|}
\hline Volume transport & & Heat gain & Salt gain \\
\hline Total & $22.3 \mathrm{~Sv}$ & $0.20 \mathrm{PW}$ & $7.8 \times 10^{6} \mathrm{~kg} / \mathrm{s}(0.22 \mathrm{~Sv})$ \\
\hline $\begin{array}{l}\text { Eastern boundary water } \\
\left(\text { East of } 8^{\circ} \mathrm{E} \text { at } 30^{\circ} \mathrm{S}\right)\end{array}$ & $66.9 \%$ & $88.8 \%$ & $86.7 \%$ \\
\hline $\begin{array}{l}\text { Intermediate water } \\
\left(\sigma_{0}>26.8\right)\end{array}$ & $45.2 \%(25.6)$ & $36.6 \%(30.1)$ & $19.5 \%(16)$ \\
\hline $\begin{array}{l}\text { Central water } \\
\left(26<\sigma_{0}<26.8\right)\end{array}$ & $39.8 \%(31.0)$ & $41.6 \%(41.0)$ & $41.3 \%(40.0)$ \\
\hline $\begin{array}{l}\text { Surface and near surface } \\
\left(\sigma_{0}<26\right)\end{array}$ & $15.0 \%(10.2)$ & $21.8 \%(17.7)$ & $39.2 \%(30.7)$ \\
\hline $\begin{array}{l}\text { Water masses that downwell } \\
\text { (from } 30^{\circ} \mathrm{S} \text { to western section) }\end{array}$ & $54.7 \%(36.2)$ & $43.9 \%(39.0)$ & $63.9 \%(53.2)$ \\
\hline $\begin{array}{l}\text { Water that warms the most } \\
\left(\Delta \operatorname{Temp}>5^{\circ} \mathrm{C}\right)\end{array}$ & $13.5 \%(13.2)$ & $50.4 \%(49.5)$ & $47.2 \%(46.5)$ \\
\hline $\begin{array}{l}\text { Interior arriving water } \\
\text { (East of } 33^{\circ} \mathrm{W} \text { at } 8^{\circ} \mathrm{S} \text { ) }\end{array}$ & $4.6 \%$ & $16.8 \%$ & $15.3 \%$ \\
\hline
\end{tabular}

Note. The following rows show the percentage of the total for the different water masses (defined in the first column). In parentheses are percentage values of the total contributed by the eastern boundary current (east of $8^{\circ} \mathrm{E}$ at $30^{\circ} \mathrm{S}$ ). 

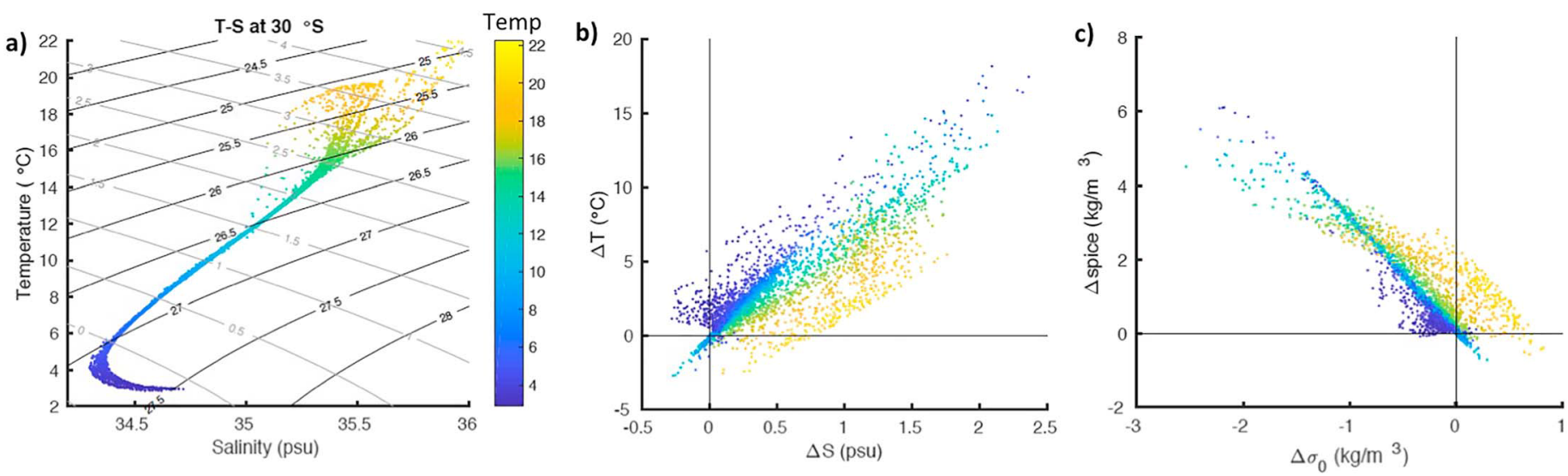

Figure 8. (a) Temperature-salinity scatter plots at $30^{\circ} \mathrm{S}$ for AMOC water masses transferring from $30^{\circ} \mathrm{S}$ to $8^{\circ} \mathrm{S}$. (b) Scatter plot of the change in temperature and salinity for particles starting at $30^{\circ} \mathrm{S}$ near the eastern boundary (longitude $>8^{\circ} \mathrm{E}$; colored by initial temperature). (c) Scatter plot of the change in density and spiciness for particles, as in (b).

particles increase their salinity more than deep particles (Figure $8 \mathrm{~b}$ and Table 3 ). This means that, for a similar increase in spiciness, the surface particles decrease their density less than the deep particles, essentially indicating the more stable character of the highly stratified near-surface waters (Figure 8c).

Where and how are particles warming? The majority of the AMOC particles crossing the ocean gain heat, apart for a small fraction that cool (Figures $8 \mathrm{~b}$ and $9 \mathrm{a}$ ) once inside the western boundary. As we have already said, most of the heat gain $\left(88.8 \%\right.$ ) occurs for $30^{\circ} \mathrm{S}$ particles departing east of $8^{\circ} \mathrm{E}$ (Table 3 and green and yellow dots in Figure 9a). This heat gain occurs through the full depth of the water column, in central (41.6\%), intermediate (36.6\%), and surface/near-surface layers (21.8\%; Table 3). About 50\% of the heat gain occurs through particles that warm over $5{ }^{\circ} \mathrm{C}$ (Table 3 ) mostly in the central and intermediate layers (green and blue in Figure $8 \mathrm{~b}$ ). In order to identify how these particles gain so much heat, we group together the particle trajectories based on the total temperature change from $30^{\circ} \mathrm{S}$ to $8^{\circ} \mathrm{S}$, as explained in section 2.5 . The average trajectories show again that the eastern particles warm most and travel further north (red lines in Figure 10d). They warm by upwelling several hundred meters when crossing the South Atlantic (especially from $30^{\circ} \mathrm{S}$ to $22^{\circ} \mathrm{S}$, red lines in Figures 10e and 10f; see also upwelling in Figure 9b) and mixing with surface warm water masses. Such large upwelling is associated with the rising of the isopycnals at the boundary between the subtropical and tropical gyres, with most warming occurring in the easternmost central and
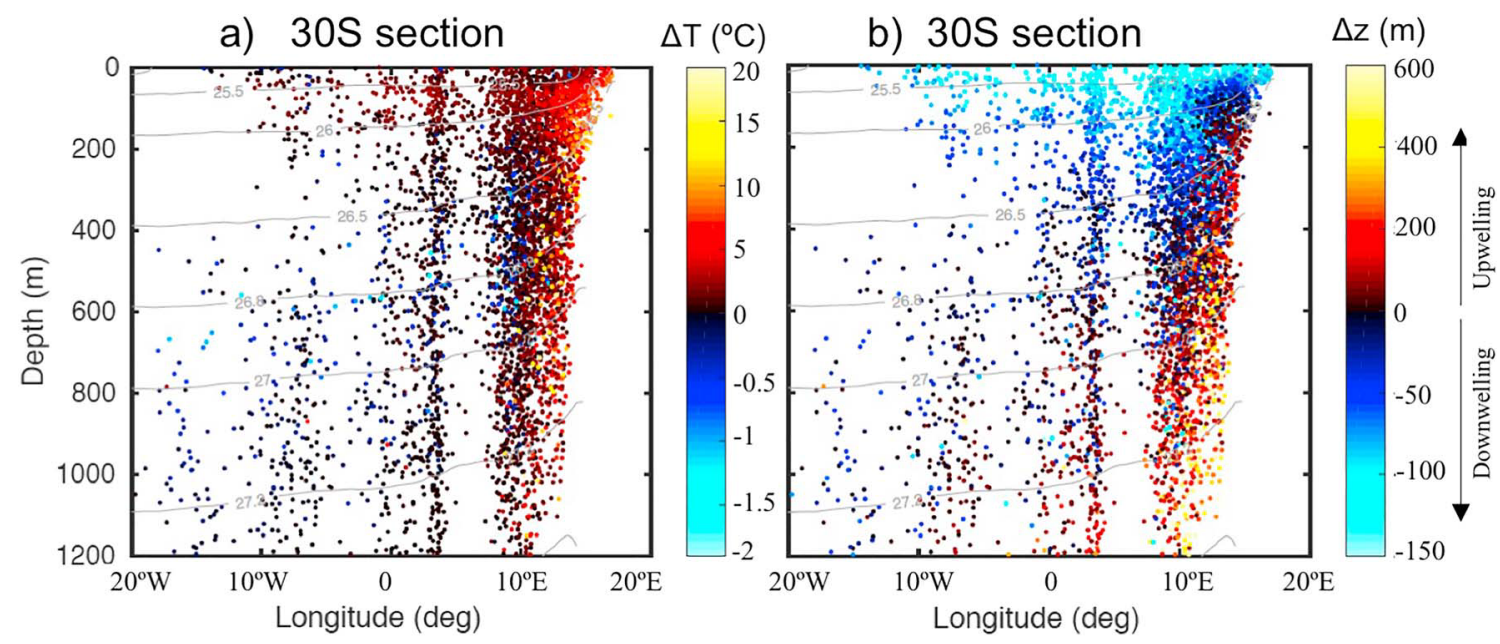

Figure 9. Depth-longitude distribution of the Atlantic meridional overturning circulation particles $\left(30^{\circ} \mathrm{S}\right.$ to $\left.8^{\circ} \mathrm{S}\right)$ in the eastern side of $30^{\circ} \mathrm{S}$, colored by (a) temperature increase from $30^{\circ} \mathrm{S}$ to the western cross section and (b) depth change $(\mathrm{m})$, positive if particles upwell and negative if particles downwell. Note that the color tables are linear, but the stretch depends on the sign of the data points. Potential density lines $\left(\sigma_{0}\right)$ are overplotted in gray. 

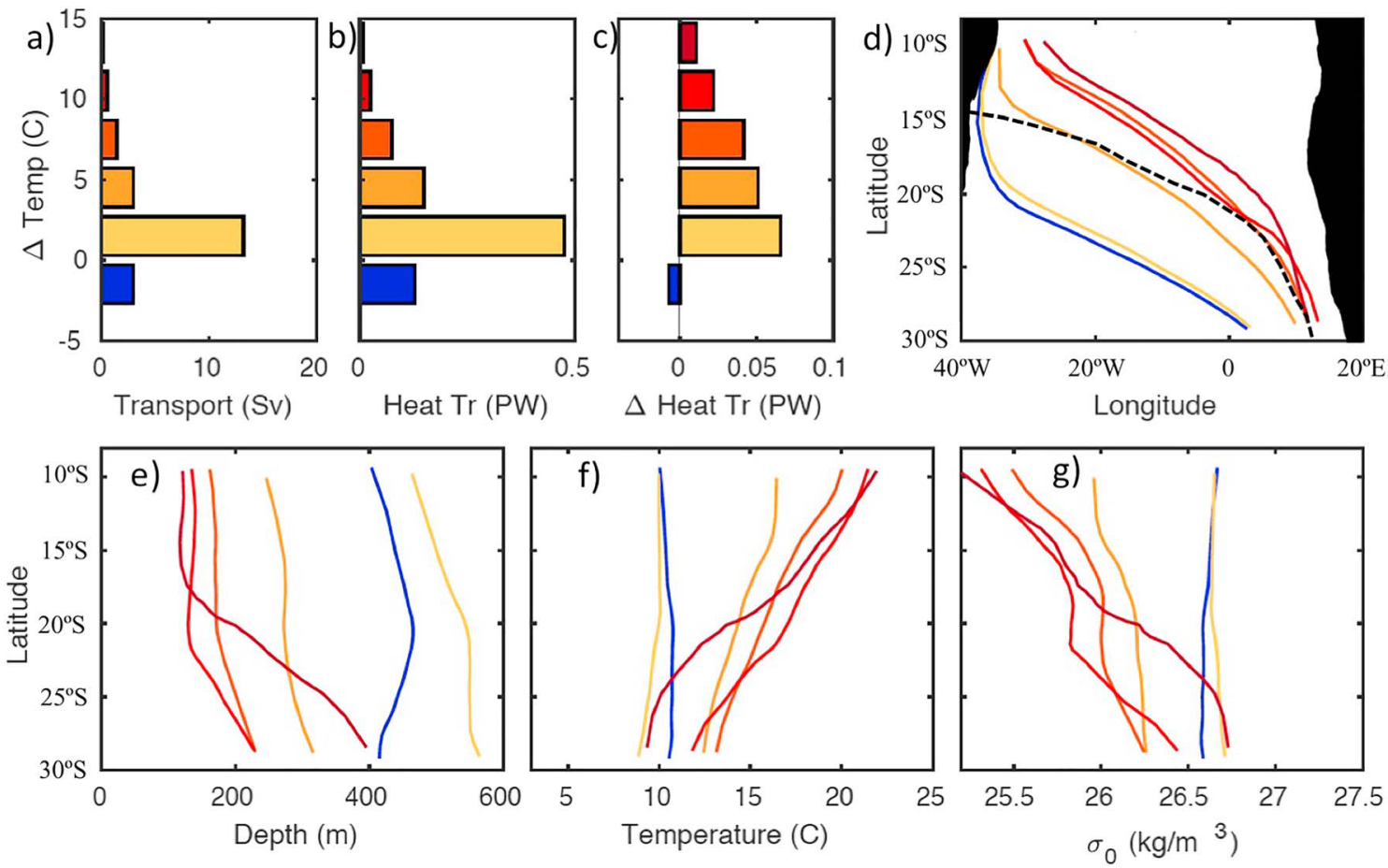

Figure 10. Histograms of (a) volume transport and (b) heat transport at $30^{\circ} \mathrm{S}$ and (c) heat gain for these particles after reaching $8^{\circ} \mathrm{S}$, binned as a function of the total temperature change. We present, for each temperature bin, (d) the mean trajectories (longitude and latitude) as well as the (e) average depth, (f) temperature, and (g) density (as a function of latitude) along these pathways; the curves are color-coded as in panels (a-c). The zero Lagrangian streamline in Figure $2 \mathrm{~d}$ is shown as a dashed line in panel (d).

intermediate layers (Figure 9a). On the other hand, surface and near-surface layers downwell along isopycnals and experience small or moderate warming (Figure 9).

\subsubsection{Other Pathways}

We next repeat the procedure of last section and explore the heat and salt gain in the other three pathways: recirculations within the subtropical and tropical gyres and transfer from the tropics to the subtropics. In particular, following section 2.5, we group the particle trajectories based on their total temperature and salt changes and summarize here the main findings.

Subtropical recirculating water masses $\left(30^{\circ} \mathrm{S}\right.$ to $\left.29^{\circ} \mathrm{S}\right)$ transfer northward $0.51 \mathrm{PW}$ of heat at $30^{\circ} \mathrm{S}$ and gain $0.04 \mathrm{PW}$ on their way to $29^{\circ} \mathrm{S}$ (salmon pink trajectory in Figure 11). While crossing the Atlantic, these particles in average downwell without much warming except for the easternmost water masses, which initially upwell and warm (similar to the eastern AMOC water masses) before submerging back to the west. However, water masses that cross $30^{\circ} \mathrm{S}$ west of $10^{\circ} \mathrm{W}$ warm only once inside the western boundary.

Tropical recirculating water masses warm and get saltier when circulating around the tropical gyre from $5^{\circ} \mathrm{S}$ to $8^{\circ} \mathrm{S}$ (three darkest blue trajectories in Figure 11). The warming $(0.08 \mathrm{PW})$ occurs only for water masses below the surface mixed layer, which first flow southeast and then warm as they move toward the western boundary (not shown). In the process, these waters also increase their salinity by $0.08 \mathrm{~Sv}$. Surface water masses that subduct in the STC (into the saltier near-surface layers) also increase their salinity by $0.10 \mathrm{~Sv}$.

Tropical water masses that feed into the subtropical southward flow do not experience any significant change in either heat or salinity (light blue trajectory in Figure 11).

\section{Discussion and Concluding Remarks}

We have combined the Connectivity Modeling System code v2.0 offline tracking software (Paris et al., 2013) and the GLORYS2V4 velocity fields (CMEMS, 2017) to backtrack particles released in the western boundary region of the tropical $\left(8^{\circ} \mathrm{S}\right)$ and subtropical $\left(29^{\circ} \mathrm{S}\right)$ South Atlantic gyres. For our analyses, we have explored 


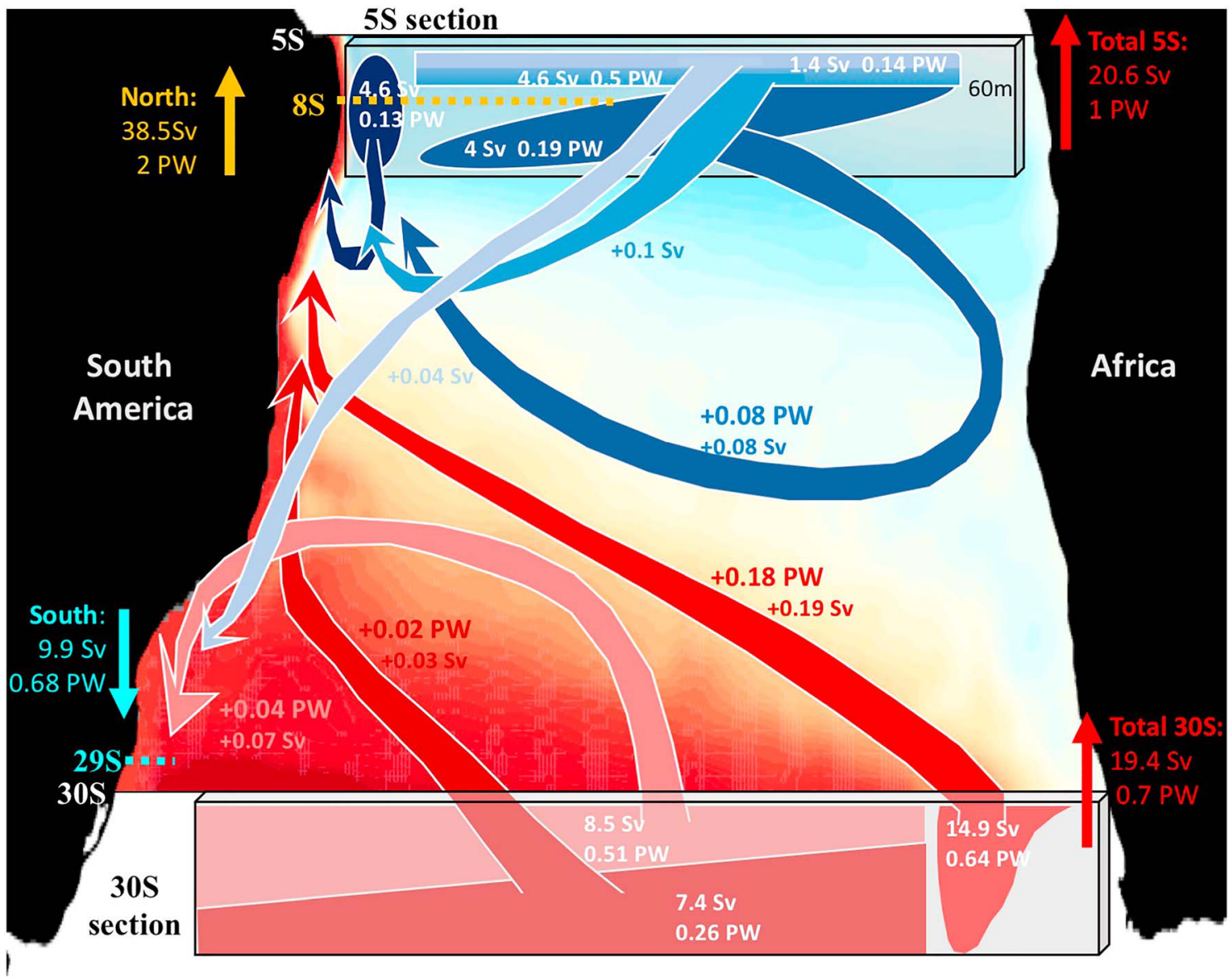

Figure 11. Schematic showing the average transfer between tropical and subtropical gyres on top of the Eulerian streamlines in Figure 1a. In red, water masses coming from the subtropical $30^{\circ} \mathrm{S}$ section (darker red if deeper). In blue, water masses coming from the tropical $5^{\circ} \mathrm{S}$ section (darker blue if deeper). The initial water-volume (Sv) and heat (PW) transports are labeled in white; the heat gain (PW) and salt transport gain (Sv) are labeled along the pathway if higher than 0.01 . The collecting sections are shown as dashed lines.

four paths of propagation down to 1,500 $\mathrm{m}$-within the subtropical and tropical gyres and the exchange between both gyres. The water masses are split among surface, near-surface, upper-thermocline (central), and intermediate strata (Table 2).

Figure 11 and Table 3 summarize the main pathways of transfer, and the volume and heat transport associated to each of these, when using mean-seasonal-cycle velocity fields and fixed diffusivities $\left(k_{\mathrm{h}}=100 \mathrm{~m}^{2} / \mathrm{s}\right.$, and $\left.k_{\mathrm{v}}=0 \mathrm{~m}^{2} / \mathrm{s}\right)$. We find that the results are qualitatively similar when adopting different diffusivities (Table 1). The conclusions are also similar when using yearly averaged velocity fields instead of climatological ones (Table 1), which suggests that seasonality does not play a significant role in the mean transfer between gyres. However, there are substantial differences across seasons, which need to be considered in order to avoid biases when looking at any particular set of field observations not averaged throughout the whole year.

The tropical gyre represents the pathway from the transoceanic $5^{\circ} \mathrm{S}$ section to the $8^{\circ} \mathrm{S}$ western boundary section, while the tropical-subtropical transfer corresponds to the transfer from the transoceanic $5^{\circ} \mathrm{S}$ section to the $29^{\circ} \mathrm{S}$ western boundary section. All the pathways starting at $5^{\circ} \mathrm{S}$ are shown in blue in Figure 11 . The initial water-volume (Sv) and heat (PW) transports are labeled in white at $5^{\circ} \mathrm{S}$, and the heat gain $(\mathrm{PW})$ and salt transport gain (Sv) are labeled along the pathways when higher than 0.01. Most subsurface tropical water masses starting at $5^{\circ} \mathrm{S}$ end up recirculating into the tropical gyres and become warmer $(0.08 \mathrm{PW})$ and saltier $(0.18 \mathrm{~Sv})$ on their way to $8^{\circ} \mathrm{S}$. In contrast, most surface tropical water masses end up transferred to the subtropical gyre, carrying $1.4 \mathrm{~Sv}$ and $0.14 \mathrm{PW}$ southward. 
The subtropical gyre is assessed as the route from the transoceanic $30^{\circ} \mathrm{S}$ section to the $29^{\circ} \mathrm{S}$ western boundary section. This pathway is formed by surface, near-surface, and central water masses that depart $30^{\circ} \mathrm{S}$ at longitudes mostly west of $8^{\circ} \mathrm{E}$ (red dots in Figure 4c). We find that the subtropical recirculating water masses warm by $0.04 \mathrm{PW}$ from $30^{\circ} \mathrm{S}$ to the western boundary at $29^{\circ} \mathrm{S}$ where they flow southward, hence being responsible for a small net southward heat transport. Talley (2003) estimated a net southward warming of $\cong 0.1 \mathrm{PW}$ at $32^{\circ} \mathrm{S}$ when excluding AMOC water masses. She defined the subtropical gyre as the region with $\sigma_{0}<26.2 \mathrm{~kg} / \mathrm{m}^{3}$ starting from the western side until the longitude where the interior northward volume transport equals the southward western boundary transport, hence leaving out the easternmost water masses with net northward transport as AMOC. To compare this value to our results, we must add the heat transport from the tropical gyre to the subtropical gyre (0.14 PW) to the net subtropical warming (0.04 PW). Hence, we effectively find a southward warming of $0.18 \mathrm{PW}$ at $29^{\circ} \mathrm{S}$, higher but comparable to the $\cong 0.1 \mathrm{PW}$ estimated by Talley (2003) at $32^{\circ} \mathrm{S}$. Talley's method is different from ours, which grants confidence to our results.

The return branch of the AMOC-the subtropical-tropical transfer-responds to the pathway from the transoceanic $30^{\circ} \mathrm{S}$ section to the $8^{\circ} \mathrm{S}$ western boundary section. It is attained through parcels in the Benguela Current spanning the entire water column (14.9 Sv), from the surface down to intermediate strata, and through intermediate water flowing across the entire subtropical basin ( $7.4 \mathrm{~Sv}$ ). All this water ends up in the NBUC and is transferred to the tropical gyre (Figure 2a), after gaining 0.20 PW and becoming saltier by $0.22 \mathrm{~Sv}$. Most of the heat and salt gain occurs for water masses of eastern origin (0.18 PW and 0.19 Sv; Table 3 ), while the rest of heat and salt is added by interior intermediate water masses (0.02 PW and 0.03 Sv). This heat gain is mostly explained by the upwelling of water masses in the easternmost central and intermediate layers that mix with more buoyant water masses along the Benguela Current and, to a lesser degree, by surface and near-surface water masses that head generally north as they depart from $30^{\circ} \mathrm{S}$ and gradually experience moderate warming and downwelling. According to Hazeleger \& Drifjhout (2006), AMOC water masses gain an additional $\cong 0.22 \mathrm{PW}$ of heat when crossing from $10^{\circ} \mathrm{S}$ to $10^{\circ} \mathrm{N}$ but freshen by $0.16 \mathrm{~Sv}$ due to intense precipitation in the tropics.

The classical Eulerian view on the meridional extent of the subtropical gyre (zero Eulerian streamline, located near $12^{\circ} \mathrm{S}$ in the western boundary in Figure 2e) is flawed as the central Atlantic includes both particles that recirculate in the subtropical gyre (orange dots in Figure 3a) and AMOC particles that flow into the tropical region (red dots in Figure 3a). Using the Lagrangian perspective allows identifying that the northern flank of the Eulerian subtropical gyre is filled with water parcels that continue north, constituting the returning limb of the AMOC, and that the bifurcation latitude between the subtropical flow and the AMOC flow shifts southward with depth (black line in Figure 1b, also see Figure 3a). The western-boundary bifurcation between the tropical and subtropical gyres is located near $21^{\circ} \mathrm{S}$, further south than expected from the Eulerian perspective (border between orange and dark blue dots in Figure $3 \mathrm{a}$ ). Note that north of $\cong 21^{\circ} \mathrm{S}$, the surface southward transport in the western boundary (Figure 1b) is explained entirely by the water masses of tropical origin that transfer into the subtropical gyre (cyan dots in Figure 3a).

Baringer and Garzoli (2007) and Majumder et al. (2016) have shown that the full-column northward heat transport at $30^{\circ} \mathrm{S}$ is $1.5 \mathrm{PW}$ when excluding the southward western boundary. Further, Mignac et al. (2018) used several reanalysis models to show that the full-column integrated net heat transport at $30^{\circ} \mathrm{S}$ is around 0.5 PW. Both results together imply that there is a southward transport of $1.0 \mathrm{PW}$ through the western boundary. Our results down to $1,500 \mathrm{~m}$ show northward transports of $0.90 \mathrm{PW}$ for AMOC particles and $0.51 \mathrm{PW}$ for the interior branch of the subtropical gyre, which together account for most of the fullcolumn 1.5 PW of northward interior transport (excluding the western boundary). In the western boundary, our results show southward transports of $0.55 \mathrm{PW}$ for subtropical particles and $0.14 \mathrm{PW}$ for tropical particles (a total of $0.69 \mathrm{PW}$ ) down to 1,500 $\mathrm{m}$, which means that the remaining southward $0.31 \mathrm{PW}$ needed to account for the full-column southward 1.0 PW are transferred at depths greater than 1,500 m.

Finally, a comparison of the western boundary transports with the total transports through the southern $\left(30^{\circ} \mathrm{S}\right)$ and the northern $\left(5^{\circ} \mathrm{S}\right)$ boundaries of the study area shows that the Lagrangian experiments account for most of the total transport in the South Atlantic (Figures $2 \mathrm{~d}$ and 2e), which means that nearly all water masses in the central South Atlantic eventually channel through the western boundary. At $5^{\circ} \mathrm{S}$, we find 20.6 $\mathrm{Sv}$ of water flowing north, which are mostly explained by the $22.3 \mathrm{~Sv}$ coming from $30^{\circ} \mathrm{S}$ (and captured at $8^{\circ} \mathrm{S}$ ) 
minus the 1.4 Sv of tropical origin that escape to the subtropics (for a total of $20.9 \mathrm{~Sv}$ ); the northward heat transport at $5^{\circ} \mathrm{S}(1.0 \mathrm{PW})$ is essentially due to the heat carried by AMOC water masses $\left(1.10 \mathrm{PW}\right.$ at $\left.8^{\circ} \mathrm{S}\right)$, plus the heat gained along the tropical gyre $(0.08 \mathrm{PW})$ and minus the heat that is transferred from the tropics to the subtropics $(0.14 \mathrm{PW})$, for a total of $1.04 \mathrm{PW}$. At $30^{\circ} \mathrm{S}$, the total integrated northward transport is $19.4 \mathrm{~Sv}$, roughly due to AMOC water masses (14.9 Sv along the eastern boundary and 7.4 Sv in the interior ocean for a total of $22.3 \mathrm{~Sv}$ ) minus tropical water masses transferred southward (1.4 Sv), a total of $20.9 \mathrm{~Sv}$; the associated northward heat transport at $30^{\circ} \mathrm{S}$ is equal to $0.70 \mathrm{PW}$, mostly due to the heat carried by AMOC water $(0.90$ PW northward) minus the heat gained along the subtropical gyre (0.04 PW southward) and minus the heat transferred from the tropics to the subtropics (0.14 PW southward), a total of $0.72 \mathrm{PW}$. This means that only about $1.5 \mathrm{~Sv}$ and $0.02 \mathrm{PW}$ of the $30^{\circ} \mathrm{S}$ flow circulate off the western boundary.

Our study has shown that numerical models are a useful tool to assess the actual changes in heat and salt content of water particles as they experience both along-isopycnal and diapycnal transformations. In particular, our results provide a good foundation for developing a future observational strategy of cross-gyre exchange. Past observations aimed at determining AMOC properties have focused mainly on the boundary transports by means of zonal arrays. However, we have shown that the zonal component of the AMOC plays a major role in the subtropical and tropical South Atlantic. Therefore, in order to best quantify the AMOC and to understand its interaction with the tropical and subtropical gyres, it would be convenient to set up meridional arrays that can monitor the zonal flows across the South Atlantic.

Acknowledgments

A. Cabré is grateful to the Beatriu de Pinos fellowship and the program Marie Curie Actions COFUND of the 7th Framework Program for Research and Technological Development of the European Union. I. Vallès-Casanova acknowledges an FPI contract (BES2015-071314) from the Spanish government. We also acknowledge funding from the Spanish government through projects VA-DE-RETRO (reference CTM2014-56987-P) and SAGA (reference RTI2018-100844-BC33). GLORYS2V4 monthly-averaged data were obtained upon request from https://www.mercator-ocean.fr/en/ solutions-expertise/how-to-access-themercator-ocean-services/let-s-defineyour-needs/. The authors are indebted to the Mercator Ocean Service for providing these reanalysis data.

\section{References}

Baringer, M. O., \& Garzoli, S. L. (2007). Meridional heat transport determined with expendable bathythermographs-Part 1: Error estimates from model and hydrographic data. Deep-Sea Research Part I-Oceanographic Research Papers, 54(8), 1390-1401. https://doi.org/ 10.1016/j.dsr.2007.03.011

Blanke, B., Arhan, M., Madec, G., \& Roche, S. (1999). Warm water paths in the equatorial Atlantic as diagnosed with a general circulation model. Journal of Physical Oceanography, 29(11), 2753-2768. https://doi.org/10.1175/1520-0485(1999)029<2753: wwpite $>2.0 . \mathrm{co} ; 2$

Boebel, O., Davis, R. E., Ollitrault, M., Peterson, R. G., Richardson, P. L., Schmid, C., \& Zenk, W. (1999). The intermediate depth circulation of the western South Atlantic. Geophysical Research Letters, 26(21), 3329-3332. https://doi.org/10.1029/1999gl002355

CMEMS (2017). Copernicus Marine Environmental Monitoring Service (CMEMS): Product user manual, available at: http://marine. copernicus.eu/documents/PUM/CMEMS-GLO-PUM-001-025.pdf, 25 pp.

Donners, J., \& Drijfhout, S. S. (2004). The Lagrangian view of South Atlantic Interocean Exchange in a global ocean model compared with inverse model results. Journal of Physical Oceanography, 34(5), 1019-1035. https://doi.org/10.1175/1520-0485(2004)034<1019: tlvosa $>2.0 . \operatorname{co} ; 2$

Drijfhout, S. S., de Vries, P., Doos, K., \& Coward, A. C. (2003). Impact of eddy-induced transport on the Lagrangian structure of the upper branch of the thermohaline circulation. Journal of Physical Oceanography, 33(10), 2141-2155. https://doi.org/10.1175/15200485(2003)033<2141:ioetot $>2.0$. co; 2

Flament, P. (2002). A state variable for characterizing water masses and their diffusive stability: Spiciness. Progress in Oceanography, 54(1-4), 493-501. https://doi.org/10.1016/S0079-6611(02)00065-4

Fratantoni, D. M., Johns, W. E., Townsend, T. L., \& Hurlburt, H. E. (2000). Low-latitude circulation and mass transport pathways in a model of the tropical Atlantic ocean. Journal of Physical Oceanography, 30(8), 1944-1966. https://doi.org/10.1175/15200485(2000)030<1944:llcamt>2.0.co;2

Ganachaud, A. (2003). Large-scale mass transports, water mass formation, and diffusivities estimated from World Ocean Circulation Experiment (WOCE) hydrographic data. Journal of Geophysical Research, 108(C7), 3213. https://doi.org.10.1029/2002JC001565

Ganachaud, A., \& Wunsch, C. (2000). Improved estimates of global ocean circulation, heat transport and mixing from hydrographic data. Nature, 408(6811), 453-457. https://doi.org/10.1038/35044048

Garzoli, S. L. (1993). Geostrophic velocity and transport variability in the Brazil-Malvinas Confluence. Deep Sea Research Part I: Oceanographic Research Papers, 40(7), 1379-1403. https://doi.org/10.1016/0967-0637(93)90118-M

Garzoli, S. L., Baringer, M. O., Dong, S., Perez, R. C., \& Yao, Q. (2013). South Atlantic meridional fluxes. Deep Sea Research Part I: Oceanographic Research Papers, 71(Supplement C), 21-32. https://doi.org/10.1016/j.dsr.2012.09.003

Garzoli, S. L., \& Gordon, A. L. (1996). Origins and variability of the Benguela Current. Journal of Geophysical Research, $101(\mathrm{C1}), 897-906$. https://doi.org/10.1029/95JC03221

Garzoli, S. L., \& Matano, R. (2011). The South Atlantic and the Atlantic Meridional Overturning Circulation. Deep-Sea Research Part IITopical Studies in Oceanography, 58(17-18), 1837-1847. https://doi.org/10.1016/j.dsr2.2010.10.063

Gordon, A. L. (1989). Brazil Malvinas Confluence-1984. Deep Sea Research, Part I, 36(3), 359-384. https://doi.org/10.1016/01980149(89)90042-3

Gordon, A. L., Weiss, R. F., Smethie, W. M., \& Warner, M. J. (1992). Thermocline and intermediate water communication between the South-Atlantic and Indian Oceans. Journal of Geophysical Research, 97C5), 7223-7240. https://doi.org/10.1029/92JC00485

Hazeleger, W., \& Drijfhout, S. (2006). Subtropical cells and meridional overturning circulation pathways in the tropical Atlantic. Journal of Geophysical Research, 111, C03013. https://doi.org/10.1029/2005JC002942

Hummels, R., Brandt, P., Dengler, M., Fischer, J., Araujo, M., Veleda, D., \& Durgadoo, J. V. (2015). Interannual to decadal changes in the western boundary circulation in the Atlantic at $11^{\circ} \mathrm{S}$. Geophysical Research Letters, 42, 7615-7622. https://doi.org/10.1002/ 2015GL065254

Jullion, L., Heywood, K. J., Naveira Garabato, A. C., \& Stevens, D. P. (2010). Circulation and water mass modification in the BrazilMalvinas Confluence. Journal of Physical Oceanography, 4O(5), 845-864. https://doi.org/10.1175/2009JPO4174.1 
Laurian, A., \& Drijfhout, S. S. (2011). Response of the South Atlantic circulation to an abrupt collapse of the Atlantic meridional overturning circulation. Climate Dynamics, 37(3-4), 521-530. https://doi.org/10.1007/s00382-010-0890-3

Lazar, A., Murtugudde, R., \& Busalacchi, A. J. (2001). A model study of temperature anomaly propagation from the subtropics to tropics within the South Atlantic thermocline. Geophysical Research Letters, 28(7), 1271-1274. https://doi.org/10.1029/2000GL011418

Majumder, S., Schmid, C., \& Halliwell, G. (2016). An observations and model-based analysis of meridional transports in the South Atlantic Journal of Geophysical Research: Oceans, 121, 5622-5638. https://doi.org/10.1002/2016JC011693

Mignac, D., Ferreira, D., \& Haines, K. (2018). South Atlantic meridional transports from NEMO-based simulations and reanalyses. Ocean Science, 14(1), 53-68. https://doi.org/10.5194/os-14-53-2018

Orúe-Echevarría, D., Pelegrí, J. L., Machín, F., Hernández-Guerra, A., \& Emelianov, M. (2019). Inverse modeling the Brazil-Malvinas Confluence. Journal of Geophysical Research: Oceans, 124, 527-554. https://doi.org/10.1029/2018JC014733

Paris, C. B., Helgers, J., van Sebille, E., \& Srinivasan, A. (2013). Connectivity modeling system: A probabilistic modeling tool for the multiscale tracking of biotic and abiotic variability in the ocean. Environmental Modelling \& Software, 42, 47-54. https://doi.org/10.1016/j. envsoft.2012.12.006

Peña-Izquierdo, J., van Sebille, E., Pelegri, J. L., Sprintall, J., Mason, E., Llanillo, P. J., \& Machin, F. (2015). Water mass pathways to the North Atlantic oxygen minimum zone. Journal of Geophysical Research: Oceans, 120, 3350-3372. https://doi.org/10.1002/2014JC010557

Poole, R., \& Tomczak, M. (1999). Optimum multiparameter analysis of the water mass structure in the Atlantic Ocean thermocline. Deep Sea Research Part I: Oceanographic Research Papers, 46(11), 1895-1921. ISSN 0967-0637. https://doi.org/10.1016/S0967-0637(99)00025-4

Rocha, C. B., da Silveira, I. C. A., Castro, B. M., \& Lima, J. A. M. (2014). Vertical structure, energetics, and dynamics of the Brazil Current System at $22^{\circ} \mathrm{S}-28^{\circ} \mathrm{S}$. Journal of Geophysical Research: Oceans, 119, 52-69. https://doi.org/10.1002/2013JC009143

Rodrigues, R. R., Rothstein, L. M., \& Wimbush, M. (2007). Seasonal variability of the South Equatorial Current bifurcation in the Atlantic Ocean: A numerical study. Journal of Physical Oceanography, 37(1), 16-30. https://doi.org/10.1175/jpo2983.1

Schmid, C. (2014). Mean vertical and horizontal structure of the subtropical circulation in the South Atlantic from three-dimensional observed velocity fields. Deep Sea Research Part I: Oceanographic Research Papers, 91(Supplement C), 50-71. https://doi.org/10.1016/j. dsr.2014.04.015

Schmid, C., Siedler, G., \& Zenk, W. (2000). Dynamics of intermediate water circulation in the subtropical South Atlantic. Journal of Physical Oceanography, 30(12), 3191-3211. https://doi.org/10.1175/1520-0485(2000)030<3191:doiwci>2.0.co;2

Schott, F. A., Dengler, M., Zantopp, R., Stramma, L., Fischer, J., \& Brandt, P. (2005). The shallow and deep western boundary circulation of the South Atlantic at $5^{\circ}-11^{\circ} \mathrm{S}$. Journal of Physical Oceanography, 35(11), 2031-2053. https://doi.org/10.1175/jpo2813.1

Schott, F. A., McCreary, J. P., \& Johnson, G. C. (2004). Shallow overturning circulations of the tropical-subtropical oceans. Earth's Climate: the Ocean-Atmosphere Interaction, 147, 261-304.

Soutelino, R. G., Gangopadhyay, A., \& da Silveira, I. C. A. (2013). The roles of vertical shear and topography on the eddy formation near the site of origin of the Brazil Current. Continental Shelf Research, 70, 46-60. https://doi.org/10.1016/j.csr.2013.10.001

Speich, S., Blanke, B., \& Cai, W. (2007). Atlantic meridional overturning circulation and the Southern Hemisphere supergyre. Geophysical Research Letters, 34, L23614. https://doi.org/10.1029/2007GL031583

Stramma, L., \& England, M. H. (1999). On the water masses and mean circulation of the South Atlantic Ocean. Journal of Geophysical Research, 104(C9), 20863-20883. https://doi.org/10.1029/1999JC900139

Talley, L. D. (2003). Shallow, intermediate, and deep overturning components of the global heat budget. Journal of Physical Oceanography 33(3), 530-560. https://doi.org/10.1175/1520-0485(2003)033<0530:siadoc $>2.0 . c 0 ; 2$

Talley, L. D. (2008). Freshwater transport estimates and the global overturning circulation: Shallow, deep and throughflow components Progress in Oceanography, 78(4), 257-303. https://doi.org/10.1016/j.pocean.2008.05.001

von Schuckmann, K., Le Traon, P.-Y., Alvarez-Fanjul, E., Axell, L., Balmaseda, M., Breivik, L.-A., et al. (2016). The Copernicus Marine Environment Monitoring Service Ocean State Report. Journal of Operational Oceanography, 9, s235-s320. https://doi.org/10.1080/ 1755876x.2016.127344 